\title{
Inventarisatie van arbeidsmarktonderzoeken onder afgestudeerden van het agrarisch onderwijs
}

Citation for published version (APA):

van Dam, J. W., \& Heijke, J. A. M. (1991). Inventarisatie van arbeidsmarktonderzoeken onder

afgestudeerden van het agrarisch onderwijs. Researchcentrum voor Onderwijs en Arbeidsmarkt, Faculteit der Economische Wetenschappen. ROA Working Papers No. 1 https://doi.org/10.26481/umarow.1991001

Document status and date:

Published: 01/01/1991

DOI:

10.26481/umarow.1991001

Document Version:

Publisher's PDF, also known as Version of record

\section{Please check the document version of this publication:}

- A submitted manuscript is the version of the article upon submission and before peer-review. There can be important differences between the submitted version and the official published version of record.

People interested in the research are advised to contact the author for the final version of the publication, or visit the DOI to the publisher's website.

- The final author version and the galley proof are versions of the publication after peer review.

- The final published version features the final layout of the paper including the volume, issue and page numbers.

Link to publication

\footnotetext{
General rights rights.

- You may freely distribute the URL identifying the publication in the public portal. please follow below link for the End User Agreement:

www.umlib.nl/taverne-license

Take down policy

If you believe that this document breaches copyright please contact us at:

repository@maastrichtuniversity.nl

providing details and we will investigate your claim.
}

Copyright and moral rights for the publications made accessible in the public portal are retained by the authors and/or other copyright owners and it is a condition of accessing publications that users recognise and abide by the legal requirements associated with these

- Users may download and print one copy of any publication from the public portal for the purpose of private study or research.

- You may not further distribute the material or use it for any profit-making activity or commercial gain

If the publication is distributed under the terms of Article $25 \mathrm{fa}$ of the Dutch Copyright Act, indicated by the "Taverne" license above, 


\section{INVENTARISATIE VAN ARBEIDSMARKT- ONDERZOEKEN ONDER AFGESTUDEERDEN \\ VAN HET AGRARISCH ONDERWIJS}

ROA-W-1991/1

J.W. van Dam en J.A.M. Heijke

Uitgevoerd in opdracht van het Ministerie van Landbouw, Natuurbeheer en Visserij

\section{RESEARCHCENTRUM VOOR ONDERWIJS EN ARBEIDSMARKT}

Faculteit der Economische Wetenschappen

Rijksuniversiteit Limburg

Maastricht, februari 1991 


\section{CIP-GEGEVENS KONINKLIJKE BIBLIOTHEEK, DEN HAAG}

Dam, J.W. van

Inventarisatie van arbeidsmarktonderzoeken onder afgestudeerden van het agrarisch onderwijs / J.W. van Dam en J.A.M. Heijke. - Maastricht : Researchcentrum voor Onderwijs en Arbeidsmarkt, Faculteit der Economische Wetenschappen, Rijksuniversiteit Limburg. (Werkdocument $=$ working paper / Researchcentrum voor Onderwijs en Arbeidsmarkt, ISSN 0922-4645; 1991/1)

Uitgevoerd in opdracht van het. Ministerie van Landbouw, Natuurbeheer en Visserij. - Met lit. opg.

ISBN 90-5321-055-5 in spiraalband

Trefw.: agrarisch onderwijs en arbeidsmarkt; Nederland; onderzoek. 


\section{INHOUDSOPGAVE}

Bladzijde

1. Inleiding 1

2. Organisaties die regelmatig onderzoek verrichten 4

2.1. Stichting Maatschappelijke Plaats Wageningse afgestudeerden (MPW) 4

2.2. Stichting Samenwerking Hoger Agrarische Onderwijs (SHAO) 5

2.3. Stichting Beroepen-Analyse Agrarische Sector (BAAS) 7

3. Incidenteel onderzoek naar de arbeidsmarkt voor agrarisch opgeleiden 10

$\begin{array}{ll}\text { Literatuur } & 13\end{array}$

$\begin{array}{ll}\text { Bijlage } & 15\end{array}$ 


\section{INLEIDING}

De directie Landbouwonderwijs van het Ministerie van Landbouw, Natuurbeheer en Visserij (LNV) heeft aan het Researchcentrum voor Onderwijs en Arbeidsmarkt (ROA) te Maastricht verzocht een inventarisatie te maken van de activiteiten die door een aantal instellingen worden ondernomen met betrekking tot het verzamelen van arbeidsmarktgegevens over afgestudeerden van opleidingen uit het landbouwonderwijs. De resultaten van deze inventarisatie zullen worden besproken op een 20 februari 1991 te houden conferentie over het arbeidsmarktonderzoek ten behoeve van het agrarisch onderwijs. Het verslag is samengesteld door J.W. van Dam en J.A.M. Heijke, met medewerking van M. Reiners.

Voor deze inventarisatie zijn brochures en rapportages verzameld van enkele organisaties uit het agrarische onderwijs. Deze organisaties zijn:

- Stichting Maatschappelijke Plaats Wageningse afgestudeerden (MPW)

- $\quad$ Stichting Samenwerking Hoger Agrarisch Onderwijs (SHAO)

- Stichting Beroepen-Analyse Agrarische Sector (BAAS)

Deze drie organisaties houden zich op reguliere basis bezig met onderzoek naar de aansluiting van het land- en tuinbouwonderwijs op de arbeidsmarkt.

Daarnaast zijn in de inventarisatie enkele onderzoekprojecten van de volgende instellingen betrokken:

- Nederlandse Ingenieursvereniging NIRIA

- $\quad$ Stichting tot Ontwikkeling van Agrarische Onderwijskunde en Scholing (STOAS)

- Landbouwuniversiteit Wageningen, Vakgroep Agrarische Onderwijskunde

- Onderzoek- en adviesbureau Regioplan

- $\quad$ Stichting Opleidingsfonds Leerlingwezen Land- en Tuinbouw (SOLLT)

Van deze rij houdt de laatstgenoemde organisatie zich bezig met een aantal opleidingen uit het leerlingwezen. De onderzoeken van de drie daarvoor genoemde organisaties waren gericht op het Middelbaar Agrarisch Onderwijs (MAO). De onderzoeken van het NIRIA zijn gericht op afgestudeerden van het 'harde HBO', waaronder het Hoger Agrarisch Onderwijs (HAO). Hiergenoemde organisaties dekken niet alle onderwijsniveaus. Voor het Lager Agrarische Onderwijs heeft nog geen structureel arbeidsmarktonderzoek plaatsgevonden. Dat is hier ook minder relevant, omdat het hier gaat om beroepsvoorbereidend onderwijs, waarbij de afgestudeerden merendeels doorstromen naar vervolgonderwijs.

Met de bovenstaande reeks zijn de belangrijkste organisaties en onderzoekinstellingen genoemd die zich bezig houden of hebben gehouden met arbeidsmarkt- en beroepsaspecten van het 
agrarisch onderwijs. Behalve deze organisaties zijn er een aantal organisaties te noemen die zich op kleinere schaal hebben beziggehouden met gegevensverzameling. Gedacht kan worden aan de activiteiten van afzonderlijke onderwijsinstellingen in het agrarisch onderwijs, bijvoorbeeld in het kader van het zogenoemde RUBS-project ${ }^{1}$. Dit project betreft de experimentele fase van de ontwikkeling van een nationale schoolverlatersenquête.

Bij de typering van het verrichte arbeidsmarktonderzoek is het van belang voor ogen te houden dat bij het onderzoek naar de aansluiting van het onderwijs op de arbeidsmarkt in het algemeen onderscheid wordt gemaakt tussen de kwalitatieve aansluitingsaspecten en de kwantitatieve aansluitingsaspecten. In het eerstgenoemde type onderzoek staat de vraag centraal of de inhoud van het onderwijs voldoende aansluiting biedt op de inhoud van de latere beroepspraktijk. Met andere woorden: of de in het onderwijs verkregen kwalificaties zijn afgestemd op de vereiste kwalificaties in de beroepsuitoefening. Bij dergelijk onderzoek worden de resultaten van functie- en beroepenanalyses geconfronteerd met de inhoud en doelstellingen van opleidingsprogramma's. Gegevens over de kwalitatieve aansluiting van het onderwijs op de beroepspraktijk worden vaak verzameld door middel van enquêtes en interviews onder afgestudeerden of werkenden in een bepaalde beroepsgroep of onder werkgevers uit eenzelfde bedrijfstak. In het kader van het zogenoemde Mantelproject is hiervoor een instrument ontwikkeld. Met behulp van dit instrument kunnen uit beroepenanalyses beroepsprofielen worden afgeleid, waarop leerplannen kunnen aansturen.

In het onderzoek naar de kwantitatieve aansluitingsaspecten staat de vraag centraal of het aantal aanbieders van arbeid met een bepaalde opleiding overeenkomt met het aantal dat op de arbeidsmarkt wordt gevraagd. Voor dergelijk onderzoek is de beschikking over representatieve en vergelijkbare databestanden noodzakelijk. Hoewel het Centraal Bureau voor de Statistiek (CBS) in het kader van de Enquête BeroepsBevolking (EBB) elk jaar een omvangrijk databestand met opleidings- en beroeps gegevens verkrijgt, zijn deze gegevens niet verfijnd genoeg om confrontaties van vraag en aanbod te maken op het niveau van afzonderlijke opleidingsrichtingen en beroepsgroepen. Daarom tracht men de vereiste gegevens te verkrijgen door enquêtes onder afgestudeerden en werkgevers. Deze enquêtes dienen grootschalig te zijn opgezet om voldoende representativiteit te krijgen naar opleiding, beroep- of functiecategorie, bedrijfstak en regio.

Bij de inventarisatie wordt getracht antwoord te krijgen op de volgende vragen:

1. Wat is de aard van de verzamelde gegevens, hun kenmerken en mate van detaillering?

1. Zie voor een verslag hiervan: A. de Grip en J.W. van Dam, Evaluatie van de RUBS-schoolverlatersenquête 1989, Maastricht, ROA-R-1990/2. 
2. Wat is de wijze van verzamelen?

- via afgestudeerden (schoolverlaters- of afgestudeerdenonderzoek);

- via werkgevers (bedrijfs- of brancheonderzoek onder werkgevers);

- via andere kanalen (experts, analyse van secundaire bronnen, e.d.);

3. Worden er prognoses opgesteld?

4. Wat is de frequentie van verzamelen en de actualiteit van de gegevens?

5. Op welke wijze heeft de presentatie van de resultaten plaatsgevonden

6. Wat zijn de gebruikersgroepen en gebruiksdoelen?

7. Welke definities en classificaties worden in het onderzoek gehanteerd?

In hoofdstuk 2 wordt voor MPW, SHAO en BAAS, na een korte karakterisering, voor elk van deze instellingen getracht bovenvermelde zeven vragen te beantwoorden. In hoofdstuk 3 komen de andere onderzoekprojecten aan de orde. In een bijlage worden alle bij het ROA bekende onderzoeken van deze instellingen beschreven. 


\section{ORGANISATIES DIE REGELMATIG ONDERZOEK VERRICHTEN}

In dit hoofdstuk zullen de organisaties, die in hoofdstuk 1 zijn genoemd, verder worden besproken. Per organisatie wordt er iets gezegd over die organisatie zelf, over de doelstellingen van die organisatie, de positie van die organisatie met betrekking tot het onderwijs en de arbeidsmarkt, en over de reeds uitgevoerde onderzoeken.

\subsection{Stichting Maatschappelijke Plaats Wageningse afgestudeerden (MPW)}

De Stichting MPW is in 1973 op initiatief van het Nederlands Instituut van Landbouwkundig Ingenieurs (NILI) opgericht met als doel de werkgelegenheidspositie van afgestudeerden van de Landbouw Universiteit Wageningen (LUW) te bevorderen. De Stichting MPW verricht daartoe onder meer systematisch onderzoek naar de arbeidsmarkt en de loopbanen van afgestudeerden van de LUW. Zij doet dit bijvoorbeeld door middel van een vijfjaarlijks loopbaanonderzoek onder alle nog werkende afgestudeerden van de LUW. De Stichting MPW is nauw verbonden met de beroepsvereniging NILI en derhalve sterk gericht op aspecten van de arbeidsmarkt en de beroepspraktijk.

De volgende arbeidsmarktonderzoeken zijn door MPW verricht:

- vijfjaarlijkse loopbaanenquêtes onder alle afgestudeerden van de LUW;

- loopbaanenquêtes onder specifieke groepen afgestudeerden van de LUW;

- onderzoeken naar het mogelijke werkterrein voor specifieke groepen afgestudeerden;

- $\quad$ onderzoek naar de aansluiting van de studie op de beroepspraktijk;

Beschrijving van de verzamelde onderzoeksgegevens:

1. Aard en detaillering: De gegevens geven zowel informatie over de kwalitatieve als de kwantitatieve aspecten van de aansluiting van het onderwijs op de arbeidsmarkt. De laatstgebruikte versie van de vragenlijst voor het loopbaanonderzoek (van 1988) onder pas afgestudeerden bevat 55 items, verdeeld over zeven onderwerpen: achtergrondgegevens, functiekenmerken, relatie tussen opleiding en loopbaan, werken in het buitenland, mobiliteit, nascholing en evaluatie van de studie. De vragenlijst voor langer dan vijf jaar afgestudeerden bevat in plaats van de rubrieken nascholing en evaluatie van de studie de rubrieken post-academisch onderwijs en verwachte werkgelegenheid.

2. Verzame/wijze: Hoofdzakelijk via enquêtes onder afgestudeerden.

3. Prognoses: Er worden geen prognoses opgesteld. Wel wordt in de enquête onder de afgestudeerden, die langer dan vijf jaar geleden hun studie afrondden, gevraagd naar een schatting van het in de komende twee jaar te verwachten aantal vacatures voor landbouw- 
ingenieurs bij de organisatie waar zij werkzaam zijn en wordt gevraagd naar de werkgelegenheidsontwikkeling op het vakgebied.

4. Frequentie en actualiteit: Het algemene loopbaanonderzoek onder afgestudeerden van de LUW vindt vijfjaarlijks plaats. Voor deze onderzoeken en de onderzoeken onder deelpopulaties wordt steeds dezelfde basisvragenlijst gebruikt zodat ook longitudinale analyses verricht kunnen worden.

5. Presentatie: De resultaten zijn gepresenteerd in rapporten. De onderzoeksdata kunnen na overleg en tegen een financiële vergoeding ter beschikking worden gesteld (op papier, tape of disk) voor secundaire analyses.

6. Gebruiksdoelen en gebruikersgroepen: Het voornaamste doel is om door voorlichting en overleg een verbetering van de kansen van afgestudeerden op arbeidsmarkt te bewerkstelligen (waar onder het bereiken van emancipatiedoelen). Daarnaast worden de gegevens verzameld ten behoeve van het post-academisch onderwijs. Gebruikersgroepen zijn studenten, afgestudeerden, de landbouwuniversiteit, werkgevers en instanties op het gebied van onderwijsplanning en arbeidsmarkt.

7. Definities en classificaties: Er wordt bij dit onderzoek gebruik gemaakt van de volgende indelingen:

- een indeling naar eigen arbeidsmarktsituatie (eigen indeling);

- een indeling naar studierichting bestaande uit 21 richtingen (herleidbaar naar de Standaard Onderwijs Indeling (SOI);

- een indeling naar functie (eigen indeling);

- een indeling naar activiteit (als men teruggaat naar het basismateriaal biedt deze indeling, in combinatie met de indeling naar functie, de mogelijkheid van een herleiding naar de CBS-beroepenclassificatie);

- een indeling naar bedrijfssector (op basis van de Standaard Bedrijfsindeling (SBI) van het CBS).

\subsection{De Stichting Samenwerking Hoger Agrarisch Onderwijs (SHAO)}

De Stichting SHAO is een samenwerkingsverband van de Agrarische Hogescholen, deels opgericht met het doel om arbeidsmarktonderzoek te verrichten. De Agrarische Hogescholen onderkennen daarmee het grote belang van regelmatig onderzoek naar de loopbaan van de afgestudeerden en de ontwikkelingen op de arbeidsmarkt. De Stichting SHAO is, als samenwerkingsverband van de Agrarische Hogescholen, nauw verbonden met het onderwijsveld.

Het doel van de Stichting SHAO is het verkrijgen van inzicht in de huidige positie van HAO- 
ingenieurs op de arbeidsmarkt en in de beroepspraktijk en de mogelijke ontwikkelingen daarvan in de toekomst. Zij verricht daartoe:

- loopbaan- en arbeidsmarktonderzoek onder afgestudeerden;

- vacature-onderzoek;

- Delphi-onderzoek onder deskundigen uit bepaalde bedrijfssectoren;

- onderzoek onder werkgevers;

\section{Beschrijving van de verzamelde gegevens:}

1. Aard en detaillering: De verzamelde gegevens geven informatie over de kenmerken van functies en de opleidingen en vaardigheden die voor deze functies vereist of gewenst zijn. De gegevens hebben dus voornamelijk betrekking op de kwalitatieve aspecten van de aansluiting van het onderwijs op de arbeidsmarkt. De gehanteerde vragenlijst is niet identiek aan de vragenlijst van MPW maar heeft daarmee wel een sterke gelijkenis.

2. Verzame/wijze: De gegevens worden verzameld via enquêtes onder afgestudeerden en door interviews en expert-meetings met werkgevers en deskundigen.

3. Prognoses: In het onderzoek onder werkgevers wordt gevraagd naar hun visie op 'de toekomst' voor wat betreft de ontwikkeling van nieuwe kennisgebieden en het aantal te verwachten vacatures voor landbouwkundig ingenieurs. Ook in het uitgevoerde delphionderzoek onder deskundigen uit de tuinbouw werd gevraagd naar verwachtingen omtrent functies en werkzaamheden van afgestudeerden van het Hoger Tuinbouw Onderwijs.

4. Frequentie en actualiteit: Tot nu toe hebben de onderzoeken onder afgestudeerden en werkgevers slechts één keer, in 1988, plaatsgevonden. Wel is in 1982 een sterk vergelijkbaar onderzoek onder $\mathrm{HAO}$-ingenieurs verricht door de Stichting MPW.

5. Presentatie: De presentatie van de resultaten heeft plaats gevonden in verschillende rapporten. Het is niet bekend of er juridische, technische of organisatorische belemmeringen zijn die het gebruik van de data voor secundaire analyses in de weg staan.

6. Gebruikersgroepen en -doelen: De gebruikersgroepen van de resultaten van de onderzoeken verricht door SHAO zijn:

- de instellingen voor Hoger Agrarisch Onderwijs (zowel voor ontwikkeling van het onderwijs als voor voorlichting aan studenten);

- de rijksoverheid, in casu het Ministerie van LNV (o.a. ten behoeve van het opstellen van het Hoger Onderwijs en Onderzoeksplan);

- de Vereniging van Afgestudeerden, de Nederlandse Ingenieursvereniging NIRIA en het Netwerk Vrouwelijke Agrarische Ingenieurs NVAI (t.b.v. de belangenbehartiging van hun leden);

- de verschillende nascholingsinstanties zoals de Stichting Post Hoger Landbouwonderwijs maar ook de eerder genoemde Agrarische Hogescholen en Verenigingen van 
Afgestudeerden;

- de LUW (t.b.v. wetenschappelijke vervolgopleidingen en tweede fase opleidingen);

- overige belangstellenden zoals instellingen voor landbouwkundig onderzoek, studieadviseurs, middelbare agrarische scholen e.d.

Meer algemene gebruiksdoelen van de onderzoekresultaten zijn voorlichting en ontwikkeling van het onderwijs ten behoeve van de aansluiting onderwijs en arbeidsmarkt.

7. Definities en classificaties: De vraagstelling met betrekking tot werkgelegenheid en werkloosheid van afgestudeerden lijkt niet overeen te komen met de standaardvraagstelling van de International Labour Organisation (ILO) en het CBS. De gebruikte classificaties/indelingen zijn:

- een indeling naar functies bestaande uit 17 functies (eigen indeling);

- een indeling naar 76 bedrijfssectoren (uitgebreide sectorindeling van het CBS);

- een indeling naar 9 studierichtingen (eigen indeling, wel koppelbaar met de Standaard Onderwijs Indeling (SOI) van het CBS).

\subsection{Stichting Beroepen-Analyse Agrarische Sector (BAAS)}

De Stichting BAAS is opgericht op 1 januari 1987 op initiatief van de Landelijke Organen van drie agrarische leerlingstelsels: voor Bosbouw en Cultuurtechniek (LSBC), voor Levensmiddelentechnologie (LSBL) en voor de Land- en Tuinbouw, Groenvoorziening en Bloemenbranche (VOLLT). Het doel van de Stichting BAAS is om binnen de agrarische sector een aantal beroepenanalyses uit te voeren ten behoeve van de agrarische beroepsopleidingen en tevens om opdrachtgevers te adviseren omtrent de relatie tussen beroepsonderwijs en arbeidsorganisaties.

De Stichting BAAS beperkte zich aanvankelijk tot het verzamelen van gegevens over de kwalitatieve aansluitingsproblematiek. Thans worden bij alle uit te voeren onderzoeken ook kwantitatieve gegevens verzameld bij werkgevers, over de situatie nu en in de nabije toekomst.

Enkele reeds uitgevoerde arbeidsmarktonderzoeken zijn enquêtes onder steekproeven van werknemers, ten behoeve van:

- beroepenanalyse bloementeelt;

- beroepenanalyse kantonniers en onderhoudswerkers weg- en waterwerken;

De overige onderzoeken zijn enquêtes onder werknemers en direct leidinggevenden over kwalitatieve en kwantitatieve aspecten en veranderingen daarin.

- beroepenanalyse voedings- en genotmiddelenindustrie, produktie en verpakkingspersoneel; 
- beroepenanalyse groenvoorziening en bijbehorend cultuur- en civieltechnisch werkgebied;

- beroepenanalyse kwaliteitszorg, produktontwikkeling en marketing in de voedings- en genotmiddelenindustrie;

- beroepenanalyse bloemschikken/-detailhandel-branche;

- beroepenanalyse bosbouw en natuurbeheer, griend- en rietcultuur;

Daarnaast is er een werkgelegenheidsonderzoek onder de bosbouw en cultuurtechnische bedrijven uitgevoerd, alsmede een vooronderzoek naar milieuberoepen in en om de agrarische sector.

De gehanteerde methode voor de beroepenanalyses is ontwikkeld in het kader van het in hoofdstuk 1 genoemde Mantelproject, uitgebreid met een methode om kwalitatieve en kwantitatieve gegevens te kunnen koppelen.

\section{Beschrijving van de verzamelde gegevens:}

1. Aard en detaillering: De verzamelde gegevens geven vooral informatie over de kwalitatieve aspecten van de aansluiting van het onderwijs op de arbeidsmarkt. Aan leidinggevenden binnen bedrijven zijn echter ook enkele vragen gesteld over de te verwachten ontwikkeling van de vraag naar arbeid.

2. Verzame/wijze: De informatie hiervoor werd verzameld via enquêtes en interviews onder zowel uitvoerende als leidinggevende beroepsbeoefenaren in verschillende soorten bedrijven. De steekproeven hiervoor werden uit verschillende adressenbestanden getrokken.

3. Prognoses: In de onderzoeken is aan de direct leidinggevenden gevraagd naar de verwachtingen omtrent de inhoudelijke veranderingen binnen de bedrijfstak en binnen de onderzochte functieprofielen, alsmede naar de verwachte kwantitatieve ontwikkeling.

4. Frequentie en actualiteit: Het onderzoek heeft in elk van de onderscheiden sectoren pas én keer plaats gevonden, maar de mogelijkheid bestaat dat dit in 1991 herhaald zal worden. De onderzoeken hebben plaatsgevonden in de periode 1988-1990 en kunnen dus als actueel gezien worden.

5. Presentatie: De resultaten zijn gepresenteerd in een verslag ('informatiemap'), een bijbehorend tabellenboek en een brochure.

6. Gebruiksdoelen en -groepen: Het doel van het onderzoek is het zodanig verzamelen van informatie over de inhoud van de beroepspraktijk en de veranderingen daarin, dat deze informatie gebruikt kan worden voor aanpassingen van agrarische beroepsopleidingen.

7. Definities en classificaties: De bij deze onderzoeken gebruikte indelingen zijn :

- een zeer verfijnde indeling naar bedrijfssoorten (eigen indeling, echter wel onder te brengen in de Standaard Bedrijfsindeling (SBI) van het CBS); 
$-9-$

- een functieniveau-indeling, afhankelijk van de doelgroep (eigen indeling);

- circa 20 clusters van activiteiten van beroepsbeoefenaren. leder activiteitencluster bevat een afgerond takenpakket (sterk wisselend per onderzoek);

- een variërend aantal beroepsprofielen (5 tot 20) op basis van de eerder genoemde activiteitenclusters, afhankelijk van de breedte van het onderzoekveld (sluit niet aan op de beroepenclassificatie). 


\section{INCIDENTEEL ONDERZOEK NAAR DE ARBEIDSMARKT VOOR AGRARISCH OPGELEIDEN}

In dit hoofdstuk wordt een aantal organisaties en onderzoeken besproken die op minder reguliere basis dan de reeds besproken organisaties, onderzoek doen of hebben gedaan naar arbeidsmarktaspecten van agrarische opleidingen.

\section{Nederlandse Ingenieursvereniging NIRIA}

De Nederlandse ingenieursvereniging NIRIA is de belangrijkste beroepsvereniging van afgestudeerden uit het 'harde HBO'. Zij verricht jaarlijks onderzoek onder schoolverlaters van het 'harde HBO'. De uitgevoerde enquête heeft betrekking op een viertal aspecten: de maatschappelijke positie, de arbeidsvoorwaarden, de attitude en de opleiding achteraf bezien. Het NIRIA is als beroepsvereniging echter vooral geïnteresseerd in de primaire- en secundaire arbeidsvoorwaarden van haar leden. Naast de genoemde schoolverlatersenquêtes worden door haar de jaarlijks salaris-enquêtes gehouden. Hoewel in de onderzoekspopulaties van beide onderzoeken altijd aandacht werd geschonken aan afgestudeerden uit het Hoger Agrarisch Onderwijs (HAO) kwamen de gegevens van 'agrarisch afgestudeerden' uit het HBO in de onderzoeksresultaten niet goed naar voren. Het NIRIA heeft daarom onlangs een aparte sectie Landbouw opgezet voor haar 1200 leden met een 'landbouwachtergrond'. Mede met het oog op de voorgenomen intensivering van de ledenwerving voor deze sectie, is in samenwerking met Verenigingen van Afgestudeerden van Hogere Agrarische Scholen eind 1990 een enquête gehouden onder circa 4.000 recent afgestudeerde landbouwingenieurs uit het HBO. Rapportage zal medio mei 1991 plaatsvinden.

\section{Stichting Ontwikkeling Agrarische Onderwijskunde en Scholing (STOAS)}

De Directie Landbouwonderwijs van het Ministerie van LNV heeft in 1986 de Stichting tot Ontwikkeling van Agrarische Onderwijskunde en Scholing (STOAS) in de gelegenheid gesteld tot het verrichten van een onderzoek naar de aard en inhoud van functies van middelbaar agrarisch gediplomeerden. Het onderzoek werd uitgevoerd in samenwerking met de Vakgroep Pedagogiek en Didactiek van de LUW. Voor dit onderzoek is gebruik gemaakt van nog niet geanalyseerde gegevens van een tweetal enquêtes van het Landbouw Economisch Instituut (LEI) in 1978 en 1983, onder 2.143 schoolverlaters van het MAO. Het onderzoek in 1978 had betrekking op herkomst en toekomstplannen van MAO-eindexamenklassers. Het onderzoek in 1983 werd verricht onder dezelfde populatie met ditmaal de arbeidsmarktbestemming als onderzoeksthema. Dit cijfermateriaal werd in dit onderzoek aangevuld met de resultaten van 
gesprekken met betrokkenen en deskundigen. Op basis hiervan zijn 57 beroepsbeschrijvingen opgesteld. In het uitgebrachte onderzoekrapport 'De MAS en dan...' is tevens een groot aantal voorstellen voor vervolgonderzoek opgenomen (zie voor verdere activiteiten van de Vakgroep Pedagogiek en Didactiek van de LUW de volgende paragraaf).

\section{Landbouwuniversiteit Wageningen, Vakgroep Agrarische Onderwijskunde}

De Vakgroep Agrarische Onderwijskunde (voorheen: Vakgroep Pedagogiek en Didactiek) van de LUW houdt zich bezig met het opstellen en uitvoeren van een projectplan voor onderzoek naar de aansluiting tussen Middelbare Agrarische Opleidingen (MAO) en de arbeidsmarkt. De eerste doelstelling van dit project is het ontwikkelen en (eenmalig) beproeven van een continu signaleringssysteem van knelpunten in de aansluiting tussen het MAO en het bedrijfsleven. Een tweede doelstelling is het geven van een feitelijke beschrijving van de beroepsloopbaan van exMAO-leerlingen en de verschuivingen die daarin nu of in de toekomst plaats vinden. In dit project wordt de relatie tussen het onderwijs en de arbeidsmarkt vanuit zowel het kwalitatieve als het kwantatitatieve aansluitingsperspectief bezien. In het kader van het projectplan worden 2 deelonderzoeken uitgevoerd.

1. Een enquête onder twee cohorten ex-leerlingen van het MAO (loopbaanonderzoek). Hierin staan 3 vraagstellingen centraal:

- een onderwijsevaluatie in het kader van output-kwaliteitsbeheer;

- beschrijving van functies en beroepen waarin ex-leerlingen terechtkomen;

- analyse van kwantitatieve werkgelegenheidsontwikkelingen.

Dit deelrapport is gaande; hierover wordt in de eerste helft van 1991 gerapporteerd.

2. Een Delphi-onderzoek onder sleutelfiguren t.b.v. beleidsaanbevelingen. Met dit onderzoek zal in 1991 worden begonnen.

Onderzoek- en adviesbureau Regioplan i.o.v. Directie Landbouwonderwijs

In 1990 heeft de Directie Landbouwonderwijs van het Ministerie van LNV een onderzoek laten verrichten door Regioplan, naar de arbeidsmarktbestemming van gediplomeerden uit het Middelbaar Agrarisch Onderwijs. Hiervoor zijn 1260 MAO-schoolverlaters uit 1985, 1987 en 1989 telefonisch benaderd. Een verslag en analyse van het onderzoek is verschenen in het rapport 'De oogst van de MAS'. Dit onderzoek heeft geresulteerd in een tweetal vervolgonderzoeken. Ten eerste is het nieuw verkregen datamateriaal vergeleken met de resultaten van het hiervoor genoemde onderzoek van LEI en STOAS. Deze vergelijking geeft een beeld van de ontwikkeling van het Middelbaar Agrarisch Onderwijs. Ten tweede zijn de belangrijkste functies die MAO-gediplomeerden vervullen, vergeleken met de positie van HAO- 
gediplomeerden. Hiervoor is het onderzoekmateriaal gebruikt van het SHAO-onderzoek uit 1988 naar de $\mathrm{HAO}$-ingenieur in functie.

\section{Stichting Opleidingsfonds Leerlingwezen Land- en Tuinbouw (SOLLT)}

De SOLLT is het opleidingsfonds binnen het leerlingstelsel voor de land- en tuinbouw, groenvoorziening en bloemenbranche. Het fonds ontvangt zijn middelen van het Ministerie van Sociale Zaken en Werkgelegenheid. Tevens moet het een beleidsplan voorleggen met voornemens omtrent de kwalitatieve en kwantitatieve versterking van het leerlingwezen. Het doel van SOLLT in het algemeen is enerzijds om voldoende vakbekwame mensen voor de betreffende bedrijfstakken op te leiden, anderzijds om mensen een grotere kans te geven op de arbeidsmarkt na afronding van de opleiding. Zij is daarmee sterk gericht op de afstemming van vraag en aanbod van vakgeschoold personeel.

In opdracht van SOLLT is een arbeidsmarktonderzoek verricht, bestaande uit:

- enquêtes onder steekproeven uit twee jaarcohorten van leerlingen, naar de voorgenomen beroepskeuze; Het betrof de studierichtingen Varkens/pluimveehouderij (helemaal) en Rundvee/varkenshouderij (gedeeltelijk);

- een enquête onder werkgevers naar de te verwachten vacatures. Het betrof werkgevers in de groenvoorziening en de bloemenbranche.

Het totale onderzoekproject had als doelstellingen:

- een beeld te vormen van de arbeidsmarktontwikkelingen;

- een beeld te vormen van de mate, waarin de opleiding van het leerlingstelsel voldoet aan de verwachtingen van zowel werkgevers als werknemers;

- een analyse van arbeidsmarktontwikkelingen in het verleden met als doel uitspraken te kunnen doen over ontwikkelingen in de toekomst. 


\section{LITERATUUR}

\section{Stichting MPW}

- Aanzet tot een marktverkenning voor stedelijke Wageningers, W.N.M. van Acht e.a., Vakgroep Cultuurtechniek, Landbouwuniversiteit Wageningen, mededelingen 94, 1986;

- De aandelen stijgen: vrouwen op de arbeidsmarkt. Een onderzoek naar loopbanen van vrouwelijke afgestudeerden van de landbouwuniversiteit, met speciale aandacht voor herintreding, M. van Diepen-Van Schaik e.a., december 1987;

- De Wageningse ir in functie: Milieuhygiëne. Loopbaanenquête 1988, L.M. Leer e.a., 1989;

- De Wageningse ir in functie. Algemeen eindrapport loopbaanenquête 1988, mei 1989;

- De inkomenspositie van de Wageningse ingenieur. Loopbaanenquête 1988, M. Bos-Boers, 1990;

\section{Stichting SHAO}

- Beroeps- en opleidingsprofielen van de studierichting Nederlandse landbouw, J.M.J. Steeghs, Den Bosch, juli 1988;

- De HAO-ingenieur in functie. Verslag van een loopbaan- en arbeidsmarktonderzoek. M.C. Gimbrère, Wageningen, november 1988;

- Inventarisatie Tuinbouw-vacatures. Deelrapport 1. Beroepsprofielenproject SRC-Tuinbouw M.C. Gimbrère e.a., Wageningen, september 1989.

- Resultaten Delphi-onderzoek. Deelrapport 2. Beroepsprofielenproject SRC-Tuinbouw. M.C. Gimbrère e.a., Wageningen, september 1990;

\section{Stichting BAAS}

- Discussie-nota, Beroepen-analyse Agrarische sector, Arnhem, januari 1990;

- Bijlage bij Discussie-nota, Beroepen-analyse Agrarische sector, Arnhem, januari 1990;

- Evaluatie-rapport, Beroepen-analyse Agrarische sector, Arnhem, juni 1990;

- Informatie-map, Produkten Beroepen-analyses, augustus 1990;

Overige organisaties

- NIRIA (1990), Vragenlijst salaris-enquête Agrarische Ingenieurs 1990;

- Vakgroep Agrarische Onderwijskunde (1989), De aansluiting tussen MAO en arbeidsmarkt. Projectplan. Landbouwuniversiteit Wageningen, juni 1989;

- Rapport opzet Loopbaanonderzoek MAO 1990 en kode-boeken (z.j.); 
- H.J. Pierik (1989). Literatuurstudie. Doel en opzet van MAO-loopbaanonderzoek. Intern verslag Vakgroep Agrarische Onderwijskunde. Januari 1989;

- H.J. Pierik (1989), Verslag van een gespreksronde over doel en opzet van het MAOloopbaanonderzoek. Intern verslag Vakgroep Agrarische Onderwijskunde. Februari 1989;

- G.A.L.M. Dohmen (1988), Het leerlingwezen in de land- en tuinbouw, groenvoorziening en bloemenbranche, en de arbeidsmarkt. Een onderzoek uitgevoerd in opdracht van de SOLLT. Landbouwuniversiteit Wageningen, Vakgroep Sociologie van de Westerse gebieden. September 1988;

- J.L. Meijers (1986), De MAS en dan..... Beroepen van gediplomeerden van het Middelbaar Agrarisch Onderwijs. Landbouwuniversiteit Wageningen, Vakgroep Pedagogiek en Didactiek. November 1986;

- M. Braams (1990), De oogst van de MAS. Een onderzoek naar de uitstroombestemming van gediplomeerden van het Middelbaar Agrarisch Onderwijs, Regioplan-publikatie nr.52. Amsterdam, april 1990;

- M. Braams (1990), De oogst van de MAS. Vervolgonderzoek: een tweetal thema's nader bekeken. Regioplan-publikatie nr.61. Amsterdam, augustus 1990. 


\section{BIJLAGE}

\section{MAATSCHAPPELIJKE PLAATS WAGENINGSE AFGESTUDEERDEN}

1.1. Vrouwen op de arbeidsmarkt - de aandelen stijgen, een onderzoek naar loopbanen van vrouwelijke afgestudeerden van de landbouwuniversiteit met speciale aandacht voor herintreding, Ir. M. van Diepen-van Schaijik, Ir.L.M. Leer en Ir. M. Bos-Boers, NILI-MPW, Wageningen, 1987.

A. Dit onderzoek heeft plaats gevonden in 1987 en is uitgevoerd door Ir. M. van Diepen-van Schaijk, Ir. L.M. Leer en Ir. M. Bos-Boers voor het NILI-MPW.

B. De onderzoeksdoelgroep bestaat uit alle 1342 vrouwelijke ingenieurs, die tussen 1950 en 1985 afstudeerden aan de Landbouwuniversiteit Wageningen. Van 1293 afgestudeerden kon het adres achterhaald worden. Zij ontvingen een vragenlijst.

C. Dit onderzoek kent een vijftal doelstellingen, te weten:

1. Het bepalen van omvang, kenmerken en wensen van de groep herintredende vrouwen met een LU-opleiding.

2. Het onderzoeken van de specifieke moeilijkheden en mogelijkheden die deze vrouwen hebben bij het (opnieuw) betreden van de arbeidsmarkt.

3. Het inventariseren van maatregelen waar deze groep gebruik van zou kunnen maken, bijvoorbeeld scholingsmaatregelen.

4. Het doen van aanbevelingen voor de verbetering van de toegang tot de arbeidsmarkt van herintredende vrouwen, op grond van de beschikbare gegevens.

5. Het geven van voorlichting aan afgestudeerden en afstuderenden met behulp van de resultaten en de ervaringen van de onderzochte groep.

D. Om de doelstellingen 1,2 en 4 te bereiken is een enquête gehouden. Als aanvulling op de onderzoeksresultaten is, naast algemene literatuur, gebruik gemaakt van gegevens uit de MPW loopbaanonderzoeken van 1973, 1978 en 1983. De informatie over regelingen en cursussen (doel 3) voor herintredende vrouwen is onder meer verkregen met medewerking van het GAB in Ede. Met het oog op de vijfde doelstelling, de voorlichting, zal een brochure worden vervaardigd.

E. In de bij de enquête behorende vragenlijst is de nadruk komen te liggen op persoonlijke kenmerken, zoals burgerlijke staat, het aantal kinderen, de leeftijd van het jongste kind en de 
zorgtaken thuis. Tevens zijn vragen opgenomen omtrent de ontwikkelingen van de loopbaan, de activiteiten tijdens een eventuele functieloze periode en de invloed daarvan op het krijgen van een baan. Veel vragen hebben betrekking op vrouwen zonder betaald werk, sinds wanneer dit het geval is, de activiteiten die men onderneemt om weer aan het werk te komen en de behoefte aan ondersteuning. Aparte aandacht wordt besteed aan vrouwen die een periode na hun afstuderen in het buitenland zijn geweest.

F. Van de 1293 vrouwen die een vragenlijst toegestuurd hebben gekregen, verzonden er 946 deze ingevuld retour. Dit is een respons van $946 / 1293 * 100 \%=73,16 \%$.

De respons verschilt tussen de verschillende groepen vrouwen. Zo is er een verschil in respons bij vrouwen die tussen 1950-1960, 1960-1970 of tussen 1970-1980 afstudeerden. Verdere verschillen in respons hadden betrekking op het al dan niet woonachtig zijn in het buitenland en het lidmaatschap van MPW.

G. De bij het onderzoek gebruikte indelingen zijn:

- een indeling naar de studiemogelijkheden van afstuderen; dit zijn er tegenwoordig 22;

- een indeling van werkgevers in groepen, waarbij er 9 groepen ontstonden.

Een vergelijking van deze classificaties met de classificaties van het CBS (SBI en SOI) is niet mogelijk op basis van alleen het onderzoekverslag.

H. Over de periodiciteit van dit onderzoek is niets bekend, maar vanwege voortdurende veranderingen op zowel de arbeidsmarkt als in het onderwijs is dit wel wenselijk om een goed beeld van de loopbanen van vrouwelijke afgestudeerden te krijgen.

I. Er zijn in de vragenlijst geen vragen opgenomen over verwachtingen met betrekking tot arbeidsmarktontwikkelingen.

J. De opzet en de resultaten van dit onderzoek zijn gepresenteerd in een rapport. Verder wordt er nog een overzicht gegeven van het beleid voor herintredende vrouwen en van de scholingsregelingen voor deze vrouwen gegeven.

K. De onderzoeksresultaten bieden voldoende aanknopingspunten voor NILI-MPW om activiteiten te ondernemen ten behoeve van de Wageningse vrouwelijke afgestudeerden in het algemeen en van de herintredende vrouwen in het bijzonder. Zo kan NILI-MPW een vrouwennetwerk opzetten ter bevordering van de mogelijkheden voor vrouwen op de arbeidsmarkt. 
1.2. Aanzet tot een marktverkenning voor stedelijke Wageningers, W.N.M.van Acht, J.T. Bakker en M. Bos-Boers, Vakgroep Cultuurtechniek, Landbouwuniversiteit Wageningen en MPW, Wageningen, 1986.

A. Dit onderzoek is uitgevoerd door de Vakgroep Cultuurtechniek van de Landbouwuniversiteit in Wageningen in samenwerking met NILI-MPW. De uitvoerende onderzoekers waren W.N.M. van Acht, J.T. Bakker en M. Bos-Boers. Het onderzoek heeft eind 1985 plaats gevonden.

B. Het onderzoek heeft plaats gevonden onder Wageningse afgestudeerden die mogelijkerwijze, gezien hun studierichting of huidige werkkring, in het stedelijk gebied werkzaam zijn. Bij het bepalen van de omvang van deze groep is gebruik gemaakt van het adressenbestand van het Nederlands Instituut van Landbouwkundig Ingenieurs, dat namen, adressen en functie en/of werkorganisatie van een groot deel van de afgestudeerden bevat. Uit dit adressenbestand zijn eerst alle afgestudeerde cultuurtechnici en tropische cultuurtechnici geselecteerd. Hierbij zijn alle afgestudeerden werkzaam bij ingenieurs- en adviesbureaus aangeschreven vanwege onzekerheid over hun vakgebied. In tweede instantie is voor de resterende groep cultuurtechnici een selectie gemaakt op grond van de opgegeven functie of werkorganisatie. Ten derde zijn ook niet-cultuurtechnici geselecteerd, die werkzaam zijn in de publieke sector in een met de cultuurtechniek aanverwant gebied. Om de lijst completer te maken is aan de respondenten gevraagd om de namen van afgestudeerden op te geven, die wel in het stedelijk gebied werkzaam zijn, maar nog niet tot de selectie behoorden.

C. Het hoofddoel van dit onderzoek is: inzicht krijgen in het werkterrein voor stedelijke cultuurtechnici. Deze doelstelling bestaat uit drie subdoelstellingen:

1. Verkrijgen van inzicht in de aard van het werkterrein;

2. Verkrijgen van inzicht in de omvang van het werkterrein;

3. Verkrijgen van inzicht in de relatie opleiding-werkterrein.

D. Als onderzoeksmethode is gekozen voor een enquête onder alle LH-ingenieurs die mogelijkerwijze, gezien hun studierichting of huidige werkkring, werkzaam zijn in het stedelijke gebied. Dit is een aantal van 247 personen, welke allen een vragenlijst toegestuurd hebben gekregen.

E. De vragenlijst bevat een aantal algemene vragen, zoals vragen over geslacht, afstudeerjaar, studierichting en pensionering. Daarnaast zijn er vragen gesteld over de aard van het werkterrein. Hierbij valt te denken aan het soort dienstverband en werkweek, de werkorganisatie, het vakgebied en de functie. Ook zijn er vragen gesteld omtrent de 
opleiding en de relatie hiervan met het werkterrein. Deze vragen richten zich op de studierichting en het vakkenpakket, de aansluiting van vakken en de functie en ten slotte de opleiding van de voorganger en opvolger. Als laatste is er nog gevraagd naar de toekomst van het werkterrein.

F. Van de 247 aangeschreven personen hebben er 167 gereageerd. Dit komt neer op een respons van $167 / 247 * 100 \%=67,61 \%$. Van deze 167 respondenten bleken er 139 personen meer dan $10 \%$ van hun tijd in het stedelijk gebied werkzaam te zijn. Deze laatste groep is verder onderzocht. Onder deze 139 respondenten bevinden zich 79 cultuurtechnici. Deze groep van 79 personen is apart genomen en vergeleken met de gehele groep.

G. De in het onderzoek gebruikte indelingen zijn:

- een indeling naar studierichting (herleidbaar tot de SOI);

- een indeling naar werkorganisatie (dit zijn er 5 (eigen indeling);

- een indeling naar vakgebieden (eigen indeling);

- een indeling naar functie, waarbij onderscheid gemaakt wordt in 7 functies (eigen indeling).

H. In het verslag staat niets over de periodiciteit van het onderzoek. Waarschijnlijk was dit eenmalig.

I. Er worden een aantal toekomstverwachtingen voor verschillende vakgebieden uitgesproken in dit rapport. Deze toekomstverwachtingen geven een beeld van de te verwachten ontwikkeling op de arbeidsmarkt.

J. De presentatie van het onderzoek heeft plaatsgevonden in de vorm van een rapport. In dit rapport worden het doel en de opzet van het onderzoek uitén gezet en worden de resultaten van de enquête gegeven. Er worden verder nog een aantal conclusies aan deze resultaten verbonden. In een bijlage is de gehanteerde vragenlijst opgenomen.

$K$. Het doel van dit onderzoek is manieren te vinden hoe cultuurtechnici hun kansen op een baan kunnen vergroten. De gebruikers van de resultaten van dit onderzoek moeten dan ook gezocht worden in de onderwijsinstellingen en onder studenten.

1.3. De Wageningse ingenieur in functie, Algemeen eindrapport van de loopbaanenquête 1989, NILI/MPW, Wageningen.

A. Deze loopbaanenquête is verricht door NILI-MPW en heeft in 1988 plaats gevonden. Deze 
enquête is reeds de vierde in een reeks van vijfjaarlijkse loopbaanenquêtes.

B. De enquête is gehouden onder alle nog levende 10.000 LU-ingenieurs, die vanaf 1950 zijn afgestudeerd en waarvan het adres achterhaald kon worden.

C. De doelstellingen van het NILI-MPW loopbaanonderzoek 1988 zijn:

- Aangeven welke plaats de LU-ingenieur op de arbeidsmarkt inneemt en welke ontwikkelingen zich hebben voorgedaan in de verschillende sectoren van de arbeidsmarkt.

- Het beschrijven van de functies en de loopbanen van LU-ingenieurs in de periode 1 september 1983 - 1 september 1988.

- Het verkrijgen van inzicht in de aansluiting van opleidingen en de beroepspraktijk van LUingenieurs, zowel van afgestudeerden volgens het 'oude' studieprogramma als volgens de 'nieuwe' studieprogramma's.

- Het verkrijgen van inzicht in de methoden van functieverwerving en de factoren die hierbij een rol spelen.

- Het peilen van de behoeften aan aanvullende opleidingen en nascholing.

D. De gehanteerde onderzoekmethode is een enquête.

E. Bij de vragenlijst wordt er verschil gemaakt tussen personen die langer dan vijf jaar zijn afgestudeerd en personen die korter dan vijf jaar zijn afgestudeerd. Aan de eerste groep personen zijn vragen gesteld over hun functie op 01.01 .83 en op 01.09.88, hun visie op de ontwikkeling van de werkgelegenheid op hun werkterrein en hun behoefte aan nascholing. Aan de tweede groep zijn vragen gesteld over hun eerste functie en hun functie op 01.09.88, hun behoefte aan nascholing en hun visie op de aansluiting van opleiding en beroepspraktijk.

F. De respons van dit onderzoek bedraagt $61 \%$. De groep respondenten vormt volgens het onderzoekverslag een betrouwbare afspiegeling van de gehele populatie van de Wageningse beroepsbevolking.

G. Er wordt bij dit onderzoek gebruik gemaakt van de volgende indelingen:

- een indeling naar arbeidssituatie (eigen indeling);

- een indeling naar studierichting bestaande uit 21 richtingen (herleidbaar naar de SOI);

- een verdeling in functie (eigen indeling);

- een indeling naar activiteit (Als wordt teruggegaan naar het basismateriaal dan bieden de gegevens over de activiteit in combinatie met gegevens over de functie, waarschijnlijk de 
mogelijkheid om de respondenten in te delen volgens de CBS-Beroepenclassificatie).

H. De loopbaanenquête onder LU-ingenieurs is een vijfjaarlijkse enquête, waarbij steeds een vergelijkbare vragenlijst wordt gehanteerd. Hierdoor ontstaat de mogelijkheid om ook analyses over meerdere jaren te maken.

I. Er worden in dit onderzoek geen prognoses gemaakt. Wel wordt er aan LU- ingenieurs, die langer dan vijf jaar geleden zijn afgestudeerd, gevraagd hun visie te geven op de ontwikkeling van de werkgelegenheid op hun werkterrein.

J. De resultaten van dit onderzoek zijn verwerkt in een rapport. Bij de resultaten wordt meteen uitleg gegeven over deze resultaten. Verder worden er in dit rapport nog een aantal aanbevelingen gedaan.

K. Het loopbaanonderzoek wordt gehouden ten behoeve van voorlichting aan de volgende doelgroepen:

- (aankomende) studenten;

- afgestudeerden;

- Landbouwuniversiteit;

- werkgevers;

- instanties op het gebied van onderwijsplanning en arbeidsmarkt.

1.4. De Wageningse ingenieur in functie, Milieuhygiëne, loopbaanenquête 1988, Ir.L.M. Leer en Ir.M. Bos-Boers, NILI-MPW, Wageningen, 1988.

A. De bij dit onderzoek gebruikte gegevens komen voort uit het eerder genoemde loopbaanonderzoek "De Wageningse ingenieur in functie, eindrapport 1988", dat in 1988 door NILI-MPW verricht is. Het rapport over de Wageningse ingenieurs in de milieuhygiëne is samengesteld door Ir.L.M. Leer en Ir.M. Bos-Boers.

B. Dit deelonderzoek is gehouden onder de 481 afgestudeerde LU-ingenieurs in milieuhygiëne.

C. De doelstellingen van dit deelonderzoek zijn identiek aan de doelstellingen van het hoofdonderzoek.

D/E. Dit deelonderzoek is gebaseerd op dezelfde enquête en vragenlijst, die gebruikt zijn bij het totale onderzoek. 
F. De respons onder de LU-ingenieurs in de milieuhygiëne bedroeg $325 / 481 * 100 \%=67,56 \%$.

G. De indelingen zijn identiek aan het hoofdonderzoek.

H. Het was de eerste maal dat een deelonderzoek onder afgestudeerden in de milieuhygiëne werd verricht.

I. Ook in het deelonderzoek is gevraagd naar de visie op de ontwikkeling van de werkgelegenheid in de milieuhygiëne.

J. De presentatie van de resultaten heeft plaatsgevonden in de vorm van een rapport. Hierin zijn geen aanbevelingen opgenomen. Wel worden er conclusies van het onderzoek gegeven. Informatie uit het onderzoekrapport mag alleen worden gereproduceerd indien toestemming van NILI-MPW ontvangen is.

K. Het gebruiksdoel en de gebruikersgroepen zijn dezelfde als bij het totale onderzoek, alleen wordt nu alles toegespitst op de milieuhygiëne.

1.5. De Wageningse ir in functie: Levensmiddelentechnologie, loopbaanenquête 1988, Ir.L.M. Leer en Ir.M. Bos-Boers, NILI-MPW, Wageningen, 1988.

A. De bij dit onderzoek gebruikte gegevens komen voort uit het loopbaanonderzoek "De Wageningse ingenieur in functie, eindrapport 1988", dat in 1988 door het NILI-MPW is verricht. Het rapport over de Wageningse ingenieur in functie in de levensmiddelentechnologie is een uitwerking van de gegevens van een kleinere groep respondenten van het gehele onderzoek en is uitgevoerd door Ir.L.M. Leer en Ir.M. BosBoers.

B. Dit deelonderzoek is gebaseerd op gegevens over de 488 levensmiddelentechnologen binnen de groep van alle afgestudeerde LU-ingenieurs.

C/D/E. De aan dit deelonderzoek ten grondslag liggende doelstellingen en vragenlijst zijn dezelfde als die, welke gebruikt zijn bij het totale onderzoek.

F. De respons onder LU-ingenieurs in de levensmiddelentechnologie bedroeg $388 / 488 * 100 \%=79,50 \%$. 
G. De bij het deelonderzoek gebruikte indelingen zijn dezelfde als de bij het totale onderzoek gebruikte indelingen.

H. Het was de eerste maal dat er een analyse op de onderzoeksresultaten van deze deelpopulatie werd gehouden. De mogelijkheid bestaat om deze, separaat aan het integrale onderzoek, vijfjaarlijks te gaan verrichten.

I. Er worden geen prognoses gemaakt. Wel is gevraagd naar de visie op de ontwikkelingen van de werkgelegenheid in de levensmiddelentechnologie.

J. De presentatie van de resultaten heeft plaatsgevonden in de vorm van een rapport, waarin in tegenstelling tot het totale eindrapport geen aanbevelingen maar conclusies zijn gegeven.

Uit dit rapport mag niets gereproduceerd worden zonder toestemming van NILI-MPW.

K. Het doel en de gebruiksgroepen zijn dezelfde als bij het totale onderzoek, alleen beperken deze zich nu tot de levensmiddelentechnologie. 


\section{STICHTING SAMENWERKING HOGER AGRARISCH ONDERWIJS}

2.1. De HAO-ingenieur in functie, een verslag van een loopbaan- en arbeidsmarktonderzoek, M.C.Gimbrère, Wageningen, 1988.

A. Dit onderzoek bestaat uit twee delen, een loopbaanonderzoek en een arbeidsmarktonderzoek. Het loopbaanonderzoek is in 1987 uitgevoerd door Ing.M. Gimbrère van de Stichting SHAO. Het arbeidsmarktonderzoek zou plaats hebben in 1989. In het bovengenoemde verslag wordt alleen het loopbaanonderzoek beschreven.

B. Het loopbaanonderzoek heeft plaats gevonden onder alle HAO-ingenieurs die vanaf 1972 zijn afgestudeerd.

C. Het onderzoek had als doelstelling: het verkrijgen van inzicht in de huidige positie van HAOingenieurs in de beroepspraktijk en de mogelijke ontwikkeling daarvan in de toekomst.

D. Als onderzoeksmethode is gekozen voor een enquête onder alle HAO-ingenieurs die vanaf 1972 zijn afgestudeerd. Voor de enquête is een optisch leesbare vragenlijst ontwikkeld.

E. De vragenlijst bevat 61 vragen verdeeld over 8 rubrieken: algemene achtergrondvragen, vragen betreffende de eerste functie, vragen over de huidige functie van de respondent, vragen over de relatie onderwijs-beroep, vragen over buitenlandervaring, vragen betreffende functieloosheid en nascholing en vragen voor vrouwen betreffende hun ervaringen in de beroepsuitoefening.

F. Er zijn in totaal 12013 vragenlijsten verstuurd. Hiervan waren er 1386 onbestelbaar, 1540 retour gekregen lijsten bleken te zijn gezonden naar personen die reeds voor 1972 waren afgestudeerd en 23 retour gekregen lijsten waren van AHS-afgestudeerden. De bereikte doelgroep bestond dus 9064 personen. Hiervan zijn 5644 exemplaren retour ontvangen. De respons is dus $5644 / 9064 * 100 \%=62,26 \%$. In de responsgroep is een lichte oververtegenwoordiging uit latere afstudeerjaren.

G. De bij dit onderzoek gebruikte indelingen zijn:

- een indeling naar functies bestaande uit 17 functies (eigen indeling);

- een indeling naar 76 bedrijfssectoren (verfijning van de Standaard Bedrijfs Indeling van het CBS);

- een indeling naar 9 studierichtingen (eigen indeling, wel koppelbaar met Standaard 
Onderwijs Indeling van het CBS).

H. Dit loopbaanonderzoek van 1987 kan gezien worden als een herhaling van een in 1982 uitgevoerd arbeidsmarkt- en loopbaanonderzoek, uitgevoerd door MPW onder de verantwoordelijkheid van de Stichting Maatschappelijke Plaats Agrarische Ingenieurs (MPAI).

I. In het loopbaanonderzoek zijn geen vragen opgenomen over de verwachtingen omtrent arbeidsmarktontwikkelingen.

J. De resultaten van het loopbaanonderzoek zijn gepresenteerd in de vorm van een rapport met aanbevelingen.

K. Doel van het loopbaanonderzoek is informatie te verzamelen over de functies die afgestudeerden vervullen, over de vakgebieden, aktiviteiten en vaardigheden die deze functies kenmerken of die voor deze functies gewenst zijn, over de sectoren van de arbeidsmarkt waar afgestudeerden werkzaam zijn en over de voorbereiding van het onderwijs op de beroepspraktijk. Verder worden er in het onderzoek ook gegevens verzameld over de reeds doorlopen nascholing en de gewenste nascholing van afgestudeerden, de concurrentie op de arbeidsmarkt door afgestudeerden van andere opleidingen, de mobiliteit en loopbaan van afgestudeerden, de mate van functieloosheid en de mogelijke oorzaken, de positie en de ervaringen van vrouwelijke afgestudeerden en over de maatschappelijke positie van afgestudeerden.

Deze informatie moet op een goed hanteerbare wijze beschikbaar komen voor de volgende instellingen en personen:

- de instellingen voor Hoger Agrarisch Onderwijs (zowel voor ontwikkeling van het onderwijs als voor voorlichting aan studenten);

- de rijksoverheid in casu het ministerie van L\&V (o.a. ten behoeve van het opstellen van het Hoger Onderwijs en Onderzoeksplan);

- de Vereniging van Afgestudeerden, de Nederlandse Ingenieursvereniging NIRIA en het Netwerk Vrouwelijke Agrarische Ingenieurs NVAI (t.b.v. de belangenbehartiging van hun leden);

- de verschillende nascholingsinstanties zoals de Stichting Post Hoger Landbouwonderwijs maar ook de eerder genoemde Agrarische Hogescholen en Verenigingen van Afgestudeerden;

- de Landbouwuniversiteit (t.b.v. wetenschappelijke vervolgopleidingen en tweede fase opleidingen);

- overige belangstellenden zoals instellingen voor landbouwkundig onderzoek, studie- 
adviseurs, middelbare agrarische scholen e.d.

2.2. Beroeps- en Opleidingsprofielen van de studierichting Nederlandse Landbouw, J.M.J. Steeghs, Den Bosch, 1988.

A. Dit project is uitgevoerd door J.M.J. Steeghs op verzoek van de studierichtingscommissie Nederlandse Landbouw en is inhoudelijk en financieel gesteund door de Stichting SHAO. Dit project bestaat uit een tweetal onderzoeken. Het loopbaanonderzoek alle afgestudeerden van de studierichting Nederlandse Landbouw in de jaren 1972-1986. Deze gegevens zijn verkregen uit het SHAO-loopbaanonderzoek "De HAO-ingenieur in functie" van 1987. Het tweede onderzoek is een werkgeversonderzoek, dat door een groep studenten van de Agrarische Hogeschool in Dordrecht is uitgevoerd in de periode januari tot juni 1988.

B. Het loopbaanonderzoek betreft een enquête onder alle afgestudeerden van de studierichting Nederlandse Landbouw van de jaren 1972-1986.

Bij het werkgeversonderzoek vindt een onderzoek plaats onder alle werkgevers in en om de agrarische sector.

C. De doelstellingen van het hele project zijn het beantwoorden van twee vragen:

- Is het mogelijk een model voor de ontwikkeling van beroeps- en opleidingsprofielen te ontwerpen, dat een duidelijke meerwaarde heeft t.o.v. de huidige werkwijzen van de studierichtingscommissie en de individuele instellingen, en dat tegenlijkertijd weinig arbeidsintensief is nadat het eenmaal is gestart?

- Hoe ziet dit model er in uitgewerkte vorm uit, welke (standaard)-routines en -procedures moeten er in de toekomst gevolgd worden en welke menskracht dient beschikbaar te zijn?

De doelstelling van het loopbaanonderzoek en het arbeidsmarktonderzoek is het verkrijgen van inzicht in de huidige positie van HAO-ingenieurs in de beroepspraktijk en de mogelijke ontwikkeling daarvan in de toekomst.

D. De werkwijze van het project bestaat uit een aantal fasen:

Fase 1: de verzameling van beroepeninformatie en de formulering van beroepsprofielen.

Fase 2: de vertaling van beroepsprofielen in opleidingsprofielen en ontwikkeling van globale onderwijsdoelen en -inhouden.

In fase 1 komen het loopbaan- en arbeidsmarktonderzoek aan bod. Deze onderzoeken maken gebruik van een enquête met bijbehorende vragenlijst.

E. De vragenlijst voor dit loopbaanonderzoek is gelijk aan de vragenlijst voor het totale 
loopbaanonderzoek "de HAO-ingenieur in functie".

Bij het werkgeversonderzoek werden vragen gesteld over de werkorganisatie, over algmene zaken zoals bijvoorbeeld het aantal werknemers in Nederland, over de functies binnen een bedrijf en over de toekomst van de functies en kenniseisen binnen een bedrijf.

F. Bij het loopbaanonderzoek waren er 5027 afgestudeerden in de Nederlandse Landbouw in de periode 1972-1986. Hiervan hebben 2917 personen een vragenlijst ingevuld. De respons is dus $2917 / 5027 * 100 \%=58,02 \%$. Alle Agrarische Hogescholen zijn in deze populatie vertegenwoordigd. Over de respons bij het werkgeversonderzoek is niets bekend.

G. Bij dit loopbaanonderzoek zijn dezelfde indelingen gebruikt als bij het totale loopbaanonderzoek. De bij het werkgeversonderzoek gebruikte indelingen zijn :

- een indeling in sektoren (gebaseerd op de Standaard Bedrijfs Indeling van het CBS);

- een indeling in functies (eigen indeling);

- een indeling in werkorganisaties (eigen indeling).

In het gehele project is gebruik gemaakt van de volgende indelingen:

- een indeling naar beroepsprofielen (eigen indeling);

- een indeling naar opleidingsprofielen (eigen indeling).

$H$. Het project lijkt eenmalig te zijn.

I. Bij het loopbaanonderzoek zijn geen prognoses gemaakt. Bij het werkgeversonderzoek zijn echter wel vragen gesteld over de visie op ontwikkelingen van functies en kwalificatie-eisen.

J. Het hele project is in het bovengenoemde rapport beschreven. Na een korte uitleg van het project, zijn de resultaten van zowel het loopbaan- als werkgeversonderzoek weergegeven. Tevens bevat het rapport de samengestelde beroepsprofielen en het bijbehorende opleidingsprofiel van Nederlandse Landbouw.

K. De gebruiker van de resulaten van dit project zijn de studierichtingscommissie en de studierichting Nederlandse Landbouw. Zij kunnen deze resultaten gebruiken voor de ontwikkeling van een opleidingsleerplan en voor de invoering van een nieuw onderwijsprogramma. 
2.3. Inventarisatie Tuinbouw-vacatures, deelrapport 1, beroepsprofielenproject SRC Tuinbouw, M.C. Gimbrére en M.J. de Jeu, Wageningen, 1989.

A. Het vacature-onderzoek werd in 1989 uitgevoerd door M.C. Gimbrére en M.J. de Jeu van SHAO.

B. Het vacature-onderzoek richt zich op de afgestudeerden van de Agrarische Hogescholen, studierichting Tuinbouw.

C. Het vacature-onderzoek is bedoeld als een aanvulling op de gegevens uit het loopbaanonderzoek. Allereerst omdat het vacature-onderzoek meer recente informatie geeft. Ten tweede omdat het enig inzicht geeft in de ontwikkeling van het aanbod van banen op de arbeidsmarkt, zowel kwalitatief als kwantitatief. Ten derde omdat het informatie geeft over de wensen en eisen die werkgevers stellen ten aanzien van bepaalde functies, voorzover zij die eisen ten minste verwoorden in de personeelsadvertentie.

D. Het vacature-onderzoek omvat een analyse van de personeelsadvertenties van de laatste twee jaar welke zich richten op de afgestudeerden van de Agrarische Hogescholen, studierichting tuinbouw. Bron voor de personeelsadvertenties is de vacaturekrant van de Stichting Horticon, de zogenaamde Horticontext. In deze krant zijn advertenties verzameld uit verschillende land- en tuinbouwbladen. De Horticontexten van 1 juli 1987 tot en met 1 juli 1989 zijn gebruikt. Hierbij zijn 786 vacatures gevonden.

E. Per advertentie werden een aantal gegevens gezocht omtrent het type functie, de code voor de sector waartoe de werkgever behoort, de naam van de werkgever, de vakgebieden die van belang zijn voor de functie, de activiteiten binnen een functie, de functie-eisen, deeltijds of voltijds functie, vaste of tijdelijke functie, standplaats en werkgebied en de oorspronkelijke bron van de advertentie.

F. Het begrip respons is voor dit onderzoek niet van toepassing.

G. De bij het onderzoek gebruikte indelingen zijn:

- een functie-indeling met 12 functies (eigen indeling);

- een sector-indeling met 16 hoofdsectoren (eigen indeling, verfijnder dan de SBI van het CBS);

- een indeling naar vakgebied (idem);

- een indeling naar activiteit (idem); 
- een indeling naar vaardigheden (eigen indeling);

- een indeling naar regio (eigen indeling);

- een indeling naar bron van vacature (eigen indeling).

H. Het betrof een eenmalig verricht onderzoek.

I. Er zijn geen prognoses gemaakt in dit onderzoek.

J. De resultaten zijn weergegeven in een deelrapport van het beroepsprofielenproject. Ten eerste is het doel en de opzet van het onderzoek uitgewerkt en vervolgens zijn de resultaten gegeven. Als laatste volgen de conclusies.

K. De gebruiksgroep is de studierichtingscommissie Tuinbouw. Deze commssie zal de uit het vacature-onderzoek verkregen informatie gebruiken ter aanvulling op het loopbaanonderzoek met als doel ontwikkeling van het onderwijs en voorlichting aan (aankomende) studenten.

2.4. Resultaten Delphi-Onderzoek, deelrapport 2 beroepsprofielenproject SRC Tuinbouw, M.C. Gimbrère en M.J. de Jeu, Wageningen, 1990.

A. Dit onderzoek is in 1989 uitgevoerd door M.C. Gimbrère en M.J. de Jeu van de Stichting SHAO.

B. De onderzoeksdoelgroep bestaat uit een groep deskundigen uit elk van de acht deelsectoren van de sector tuinbouw.

C. Het doel van het Delphi-onderzoek is inzicht te krijgen in de toekomstige ontwikkelingen in de sector tuinbouw en de gevolgen daarvan voor de functies van HTuO-ingenieurs (zowel kwalitatief als kwantitatief). Het onderzoek is bedoeld als een aanvulling op de gegevens die in andere onderzoeken worden verzameld en die meer de huidige situatie beschrijven.

D. Als onderzoeksmethode is gekozen voor een Delphi-onderzoek. Een groep deskundigen is gevraagd een aantal vragen te beantwoorden over hun visie op de toekomst van de tuinbouw. Deze vragen zijn gesteld in twee schriftelijke vraagrondes, waarbij de resultaten van de eerste ronde verwerkt konden worden in de vragen van de tweede ronde.

E. In de eerste ronde kregen de deelnemers een lijst van stellingen voorgelegd over belangrijke ontwikkelingen in de tuinbouw. De deelnemers werd gevraagd om aan te geven of zij het 
eens of oneens waren met deze stellingen en op grond van welke argumenten. Vervolgens werd hen gevraagd welke functies of ontwikkelingen in functies voor HTUO-ingenieurs zij voorzagen in de verschillende sectoren van de tuinbouw. De tweede vragenlijst ging meer in op de mogelijke functies voor afgestudeerden van het HTuO en de voorbereiding op die functies door het onderwijs.

F. In de eerste ronde vulden 34 van de 41 deelnemers de vragenlijst in. De respons was hier $34 / 41 * 100 \%=82,92 \%$. In de tweede ronde vulden slechts 29 deelnemers de vragenlijst in en was de respons dus $29 / 41 * 100 \%=70,73 \%$.

Uit elke sector was minstens één deelnemer aanwezig. Dus de representativiteit kan redelijk genoemd worden.

G. De bij dit onderzoek gebruikte indeling is een indeling naar acht deelsectoren van de sector tuinbouw (eigen indeling).

H. Het onderzoek is niet periodiek.

I. In dit onderzoek worden verwachtingen uitgesproken omtrent de toekomst van de sector tuinbouw.

J. De resultaten van het Delphi-onderzoek zijn weergegeven in de vorm van een deelrapport als gedeelte van het beroepsprofielenproject van de SRC Tuinbouw. Hierin worden het doel, de opzet van het onderzoek en de resultaten gepresenteerd.

K. De resultaten van dit onderzoek zijn bestemd voor de studierichtingscommissie tuinbouw. Deze commissie gebruikt de resultaten uit het delphi-onderzoek, te zamen met de resultaten uit het vacature-onderzoek en het literatuuronderzoek, om zeven uitgebreide conceptprofielen te construeren. 


\section{STICHTING BEROEPEN-ANALYSE AGRARISCHE SECTOR}

3.1. Beroepenanalyse Bloementeelt, Informatiemap Produkten Stichting BAAS, Arnhem, 1990.

A. De beroepenanalyse in de bloementeelt is in het voorjaar 1988 uitgevoerd door onderzoekers van de Stichting Baas in samenwerking met vele anderen. Dit onderzoek stond onder leiding van G.J.L. Willems. Er kan een herhalingsonderzoek plaats vinden, welk eventuele veranderingen in de beroepspraktijk moet signaleren, zodat daarmee in de beroepsbegeleidende programma's rekening kan worden gehouden. Slechts via een proces van continue herhaling zal het mogelijk zijn de steeds veranderende beroepspraktijk in beeld te brengen ten behoeve van het beroepsonderwijs.

B. De onderzoekspopulatie bestaat uit een aantal groepen van beroepsbeoefenaars, die werkzaam zijn in verschillende soorten bedrijven in de bloementeelt. Van deze doelgroep is een steekproef genomen. De bepaling van de steekproef geschiedde als volgt. Via de N.V.Databank te Woerden werd het bestand aan bloementeeltbedrijven van de gezamelijke Kamers van Koophandel aangekocht (ca 4000 adressen). Hieruit werd een aselecte steekproef getrokken van 1291 adressen. Inclusief reeds eerder retour ontvangen antwoordkaarten van een ander adressenbestand bedroeg de totale steekproefomvang 1329 adressen. De enquêtes werden na telefonische afspraak door een aantal personen afgenomen. Vanwege het slechte resultaat van deze manier van afspraken maken werd besloten om voor het resterende aantal interviews (minder dan $10 \%$ van het totaal) op andere wijzen afspraken voor enquêtes te maken. Het gaat hierbij om adressen van bedrijven, die via derden werden verkregen.

C. De doelstelling van het onderzoek is een goed beeld te krijgen van de beroepspraktijk in de bloementeelt aan de hand van een aantal beroepsprofielen. Het doel hiervan is dan weer om tot een betere afstemming te komen tussen de opleidingsinhoud in de bloementeelt en de beroepspraktijk. Hiervoor is het noodzakelijk te weten welke diverse activiteiten er binnen arbeidsorganisaties uitgevoerd worden.

D. Als onderzoeksmethode is gekozen voor een enquête binnen een aselecte steekproef. Bij deze enquête werd gebruik gemaakt van een vragenlijst, waarvan de resultaten via de computer verwerkt zijn.

E. Deze vragenlijst bevat de mogelijke activiteiten/werkzaamheden, die in bloementeeltbedrijven voorkomen. Ook bevat de lijst een aantal vragen betreffende de achtergrondgegevens van de 
respondenten, zoals bijvoorbeeld geslacht, leeftijd, soort bedrijf, gewenste vooropleiding etc.. Tevens is gevraagd naar het wenselijke scholingsaanbod binnen de bloementeelt.

F. De respons van dit onderzoek is $353 / 1329 * 100 \%=26,56 \%$. De absolute realisatie van 353 komt overeen met de opzet van 350 .

De representativiteit is redelijk als gekeken wordt naar de verdeling van de respondenten over de verschillende functies die respondenten bekleden en naar de verschillende soorten bedrijven waarin de respondenten werkzaam zijn.

G. De bij het onderzoek gebruikte indelingen zijn :

- een bedrijfsindeling met 7 bedrijfssoorten (verfijnde eigen indeling);

- een functie-indeling met 6 functies (eigen indeling);

- 21 clusters, waarvan elke cluster een groot aantal activiteiten omvat (verfijnde eigen indeling);

- 9 beroepsprofielen (eigen indeling).

H. Het onderzoek is nog niet periodiek, maar om een zo goed mogelijk beeld van de beroepspraktijk te krijgen is dit wel noodzakelijk. De mogelijkheid bestaat dat begin 1991 een herhaling van dit onderzoek plaats heeft.

I. In dit onderzoek worden geen prognoses opgesteld.

J. De resultaten van het onderzoek zijn gepresenteerd in de vorm van een rapport. Dit rapport bestaat uit twee delen: een verslag en een tabellenboek. In het verslag wordt duidelijk waarom er tot een dergelijk onderzoek besloten is. Verder wordt de werkwijze van het begin, de bepaling van een steekproefomvang, tot het eind, een schriftelijke beschrijving en verwerking van de resultaten, beschreven. In het tabellenboek worden dan de kwantitatieve resultaten van het onderzoek vermeld.

De toegankelijkheid bestaat eruit dat alleen maar met schriftelijke toestemming van de Stichting Baas iets uit deze rapportage mag worden vermenigvuldigd en/of openbaar gemaakt.

K. De gebruiksgroep is het beroepsonderwijs en het gebruiksdoel is de eventuele aanpassing van beroepsbegeleidende programma's door dit beroepsonderwijs. 
3.2. Beroepenanalyse Kantonniers en Onderhoudswerkers weg- en waterwerken leidinggevenden en uitvoerenden, Informatiemap Produkten Stichting BAAS, Schaarsbergen, 1989.

A. Deze beroepenanalyse is medio 1988 uitgevoerd op initiatief van het Leerlingstelsel Bosbouw, Cultuurtechniek en de Groene Sector. Het onderzoek stond onder leiding van G.J.L.Willems. Het is de bedoeling dat er een herhaling van dit onderzoek in de toekomst plaats zal vinden om op de hoogte te blijven van het steeds veranderende beeld van de beroepspraktijk.

B. De onderzoeksdoelgroep bestaat uit beroepsbeoefenaren, ingedeeld naar functie en arbeidsorganisatie. Van deze doelgroep is er een steekproef ter grootte van 224 personen genomen. Gemeenten en particuliere bedrijven, die zich bezig houden met het onderhoud van wegen en vaarwegen, zijn buiten de steekproef gehouden. De responten, die gevraagd zouden worden aan dit onderzoek mee te werken, werden geselecteerd (a-selectief) uit het laatste jaarboek van de Rijkswaterstaat en de laatste uitgave van de Almanak van Waterschappen. Er werden 95 arbeidsorganisaties geselecteerd voor het afnemen van de enquête. Bij deze bedijven zouden dan meerdere beroepsbeoefenaars gevraagd worden de enquête in te vullen.

C. De doelstelling van het onderzoek is een zicht te krijgen op de inhoud van de werkzaamheden van beroepsbeoefenaars, welke zijn aan te duiden met de benaming "Kantonniers en Onderhoudswerkers weg- en waterwerken". De informatie uit de beroepspraktijk zou het uitgangspunt moeten vormen voor de daarop af te stemmen beroepsopleidingen.

D. De onderzoeksmethode bestaat uit een enquête, welke binnen een steekproef van beroepsbeoefenaars binnen deze sector gehouden is. Voor deze enquête is er een vragenlijst ontwikkeld, waarvan de antwoorden via de computer verwerkt werden.

E. Deze vragenlijst bevat niet alleen een lijst met mogelijke activiteiten, welke een beroepsbeoefenaar binnen een bedrijf kan uitvoeren.

Tevens is er gevraagd naar de arbeidsorganisatie, waarbij hij werkzaam is, en naar enkele achtergrondgegevens, zoals geslacht, leeftijd, vooropleiding, functienaam enz.. Ten slotte is er gevraagd naar het wenselijke arbeidsaanbod binnen het vakgebied en naar de toekomstperspectieven voor de beroepsbeoefenaars. 
F. In totaal komt de steekproefrealisatie overeen met 223 respondenten. Dit stemt t.o.v. een planning van 225 respondenten tot tevredenheid. De procentuele respons is $223 / 224 * 100 \%=99,55 \%$. De representativiteit is minder, want er wordt gesteld dat gemeenten en particuliere bedrijven buiten beschouwing gelaten worden vanwege problemen, die opname van deze organisaties in de steekproef met zich mee zou brengen.

G. De bij het onderzoek gebruikte indelingen zijn :

- een functie-indeling met 4 functies (eigen indeling);

- een arbeidsorganisatie-indeling met 4 organisaties (eigen indeling);

- een werkzaamheden-indeling bestaande uit 4 categorieën (eigen indeling);

- een beroepsprofielen-indeling bestaande uit 7 profielen (eigen indeling);

- een activiteitencluster-indeling met 21 clusters (eigen indeling).

H. Het onderzoek is voor zover bekend maar één keer uitgevoerd. Maar vanwege de vele veranderingen in de beroepspraktijk is het een noodzaak dat er vaker een dergelijk onderzoek verricht wordt.

I. In dit onderzoek worden er geen prognoses gemaakt. Wel wordt de respondenten gevraagd naar hun toekomstperspectieven.

J. De resultaten van het onderzoek zijn gepresenteerd enerzijds in de vorm van een rapport en anderzijds in de vorm van een tabellenboek. De toegankelijkheid bestaat eruit dat uit dit rapport niets mag worden vermenigvuldigd en/of openbaar gemaakt, zonder voorafgaande schriftelijke toestemming van de Stichting BAAS.

K. De uit dit onderzoek verkregen informatie is vooral van belang voor personen die, nadat uitspraken zijn gedaan over de vormen van beroepsopleidingen welke inhoud gegeven moeten worden, het verdere ontwikkelingswerk inhoud moeten geven. De uit dit onderzoek resulterende beroepsprofielen vormen de basis waarop het beroepsonderwijs in samenspraak met het bedrijfsleven beroepsopleidingsprofielen kan samen stellen.

3.3. Beroepenanalyse leidinggevend en uitvoerend personeel in de produktie en verpakking in de voedings- en genotmiddelenindustrie, Informatiemap Produkten Stichting BAAS, Arnhem, 1990.

A. Deze beroepsanalyse is in 1989 uitgevoerd door de Stichting BAAS. Er had reeds een vooronderzoek in deze industrie plaats gevonden in 1988. Op basis van de resultaten van dit 
vooronderzoek was besloten één onderzoek naar de functies van verpakking- en produktiepersoneel uit te voeren voor de gehele voedings- en genotmiddelenindustrie, uitgezonderd de sector (pluimvee) vleesverwerking ${ }^{2}$.

B. De onderzoeksdoelgroep bestaat uit beroepsbeoefenaars, ingedeeld naar functie en produktiesector, in de voedings- en genotsmiddelenindustrie. Uit deze doelgroep is een steekproef van 1184 beroepsbeoefenaars uit 648 bedrijven genomen. Voor het benaderen van bedrijven is gebruik gemaakt van het adressenbestand van de bedrijfstak, welk verkregen is via de Data-bank van de vereniging van Kamers van Koophandel en Fabrieken.

C. De doelstelling van het onderzoek is een zodanig beeld over de beroepspraktijk van deze industrie te verkrijgen, zodat opleidingen wat betreft inhoud en structuur herijkt kunnen worden. Dit ijken is immers nodig, omdat bedrijven zich voortdurend ontwikkelen op technisch en technologisch gebied om positieve bedrijfsresultaten te blijven behalen. Dit heeft tot gevolg dat functies en functie-inhouden kunnen veranderen.

D. Als onderzoeksmethode is gekozen voor een enquête binnen een steekproef. Bij deze enquête werd er gebruik gemaakt van een vragenlijst, waarvan de resultaten via een computer zijn verwerkt en geanalyseerd.

E. De vragenlijst bestaat uit de verschillende activiteiten, welke een beroepsbeoefenaar kan verrichten in een produktiesector. Verder zijn er nog enkele vragen gesteld over de achtergrond van de betreffende beroepsbeoefenaar (o.a. geslacht, leeftijd, vooropleiding, functienaam).

Verder is er nog een aparte vragenlijst opgesteld. Binnen elk bedrijf is vervolgens aan én leidinggevende gevraagd om (ook) deze aparte vragenlijst in te vullen. Hierin is gevraagd naar het personeelsbestand en ontwikkelingen daarin en naar mogelijke veranderingen in functieinhouden met gevolgen voor het opleidingsniveau. Zodoende is niet alleen mogelijk om aan te geven hoe een bepaald beroep eruit ziet, maar ook de trend waarin de werkgelegenheid zich ontwikkelt voor de betreffende beroepsgroep.

F. De respons van de beroepsbeoefenaren op de eerste vragenlijst is beperkt. Slechts 708 van de 1184 vragenlijsten zijn ingevuld retour ontvangen; dit is een percentage van $708 / 1184 * 100 \%=59,79 \%$. De respons van de gevraagde leidinggevenden op de tweede vragenlijst was 213 van de 648 ofwel $213 / 648 * 100 \%=32,87 \%$. Over de representativiteit

2. Voor deze sector was reeds een dergelijk onderzoek in het voorjaar van 1989 uitgevoerd. 
kan niet veel gezegd worden, aangezien vele bedrijven hun medewerking weigerden. Verder zijn ook niet alle van te voren omschreven functies of in onvoldoende mate vertegenwoordigd in de bedrijven.

G. De bij het onderzoek gebruikte indelingen zijn :

- een activiteitencluster-indeling bestaande uit 19 clusters;

- een indeling naar produktiesectoren met 42 verschillende sectoren;

- een functie-indeling bestaande uit 13 functies;

- een indeling in 9 beroepsprofielen.

Alle deze indelingen zijn eigen indelingen van de Stichting BAAS.

H. Hoewel dit onderzoek gebaseerd is op een vooronderzoek, kan het nog niet periodiek genoemd worden. Hehalingen van dit onderzoek zijn echter wel wenselijk vanwege de voortdurende ontwikkelingen in de beroepspraktijk.

I. Er worden in dit onderzoek geen prognoses gemaakt behalve dan een trend waarin de werkgelegenheid zich ontwikkelt voor de betreffende beroepsgroep.

J. Het rapport bestaat uit twee delen : een verslag over de gevolge methode en beschrijving van de resultaten en een tabellenboek met de kwantitatieve uitkomsten van het onderzoek.

Over de toegankelijkheid wordt gezegd dat niets uit dit rapport mag worden vermenigvuldigd en/of openbaar gemaakt zonder voorafgaande schriftelijke toestemming van de Stichting BAAS.

K. De gebruikersgroep is het beroepsonderwijs met betrekking tot de voedings- en genotsmiddelenindustrie, die deze informatie kan gebruiken om, met inachtneming van het onderwijsconcept, de toetsing van de opleidingsinhouden en hun onderlinge structurering plaats te laten vinden.

\subsection{Beroepenanalyse Leidinggevende en Uitvoerende Beroepsbeoefenaren in de} Groenvoorziening en bijbehorend Cultuur- en Civieltechnisch werkgebied, Informatiemap Produkten Stichting BAAS, Arnhem, 1990.

A. De beroepenanalyse onder leidnggevende en uitvoerende beroepsbeoefenaren in de groenvoorziening en bijbehorend cultuur- en civieltechnisch werkgebied is in 1989 uitgevoerd door Stichting BAAS. Van dit onderzoek heeft nog geen herhaling plaats gevonden, maar ook hier geldt weer dat voor een goed beeld van de steeds veranderende beroepspraktijk dit wel 
nodig is. $\mathrm{Er}$ is wel al een initiatief genomen om de beroepenanalyse uit te breiden tot een "geïntegreerde" analyse, waarbij ook elementen als het verloop van de bezetting van functies binnen bedrijven en de ontwikkelingen van functie-inhouden worden geïnventariseerd.

B. De onderzoeksdoelgroep bestaat uit beroepsbeoefenaars, die ingedeeld zijn het soort arbeidsorganisatie, waarvoor ze werken, en naar het soort functie, die zij daar vervullen. Er wordt gebruik gemaakt van een steekproef. Deze is aselect genomen uit het Kamer van Koophandelbestand, en bij de categorieën waarbij dit niet mogelijk was (b.v. gemeenten en overheid) uit andere beschikbare bronnen, waarbij steeds werd gelet op een goede spreiding in grootte van de organisatie en geografische ligging. Er werd gestreefd naar een gepland aantal enquêtes van 583 .

C. De doelstelling van het onderzoek is om de opleidingen, gericht op leidinggevende en uitvoerende functies in de groenvoorziening en bijbehorend cultuur- en civieltechnisch werkgebied, wat betreft inhoud en structuur te kunnen herijken. Dit is nodig omdat bedrijven zich voortdurend ontwikkelen om positieve bedrijfsresultaten te blijven behalen. Dit heeft tot gevolg dat functies en functie-inhouden kunnen veranderen.

D. Als onderzoeksmethode is gekozen voor een enquête binnen de vastgestelde steekproef. Bij deze enquête is er gebruik gemaakt van een tweetal vragenlijsten. Eén vragenlijst gericht op zowel uitvoerende en leidinggevende beroepsbeoefenaars en één vragenlijst gericht op én leidinggevende binnen elk bedrijf. Verwerking en analyse van de verzamelde gegevens heeft plaats gevonden via de computer.

E. De vragenlijsten voor zowel uitvoerenden als leidinggevenden bevat de mogelijke activiteiten, die een beroepsbeoefenaar kan uitvoeren binnen een bedrijf. Tevens is er gevraagd naar een aantal achtergrondgegevens, zoals geslacht, leeftijd, vooropleiding enz.. In de aparte vragenlijst voor één leidinggevende binnen het bedrijf is er gevraagd naar het personeelsbestand, de ontwikkelingen daarin en de mogelijke veranderingen in functieinhouden met gevolgen voor het opleidingsniveau. Hierdoor is het mogelijk aan te geven hoe de trend eruit ziet, waarin de werkgelegenheid zich ontwikkelt voor de betreffende beroepsgroep en in welke richting de beroepsinhouden zivh globaal de komende tijd gaan ontwikkelen.

F. De respons van dit onderzoek m.b.t. de eerste vragenlijst is $522 / 583 * 100 \%=89,53 \%$. De respons voor de tweede vragenlijst is $246 / 590 * 100 \%=41,69 \%$. De representativiteit is redelijk, aangezien er bij het nemen van een steekproef rekening gehouden is met de 
spreiding in de grootte van de organisatie en de geografische ligging. Verder zijn in de respons alle van te voren bepaalde arbeidsorganisaties en bijna alle functietypen vertegenwoordigd.

G. De bij het onderzoek gebruikte indelingen zijn :

- een functie-indeling bestaande uit 8 functies;

- een indeling naar 10 typen arbeidsorganisaties;

- een activiteitenculsterindeling met 19 clusters;

- een beroepsprofielenindeling bestaande uit 10 profielen;

- een 16-tal subprofielen.

Alle gebruikte indelingen zijn eigen indelingen.

$H$. Het onderzoek is nog niet periodiek, maar dit is wel wenselijk gezien de steeds veranderende beroepspraktijk.

I. Er worden geen duidelijke prognoses gemaakt. Wel wordt er een trend gegeven, waarin de werkgelegenheid zich ontwikkelt in de betreffende beroepsgroep, en de richting, waarin de beroepsinhouden zich de komende tijd globaal gaan ontwikkelen.

J. De presentatie van het onderzoek bestaat uit een verslag, een tabellenboek en een supplement bij het tabellenboek.

De toegankelijkheid bestaat eruit dat alleen maar met schriftelijke toestemming van de Stichting BAAS iets uit deze rapportage vermenigvuldigd en/of openbaar gemaakt mag worden.

K. De gebruikersgroep is het beroepsonderwijs, die de resultaten van dit onderzoek kan gebruiken, met inachtneming van het onderwijsconcept, voor de toetsing van de opleidingsinhouden en hun onderlinge structurering. 


\section{STOAS: STICHTING TOT ONTWIKKELING VAN AGRARISCHE ONDERWIJSKUNDE EN SCHOLING}

4.1. De MAS en dan..., beroepen van gediplomeerden van het middelbaar agrarisch onderwijs, J.L.Meijers, Wageningen, 1986.

A. In het kader van het Werkgelegenheidsproject Onderwijs heeft de Directie Landbouwonderwijs van het Ministerie van Landbouw, Natuurbeheer en Visserij aan de STOAS een projectplaats ter beschikking gesteld ten behoeve van een onderzoek naar de functies van MAO-gediplomeerden. De hiervoor aangetrokken onderzoekster J.L.Meijers is vervolgens gedetacheerd bij de Vakgroep Pedagogiek en Didactiek van de LU in Wageningen, die de zorg heeft gekregen voor de inhoudelijke begeleiding.

B. Onderzoeksdoelgroep is een steekproef van MAO-gediplomeerden. Aangezien voor dit onderzoek de gegevens van het LEl-onderzoek van 1983 zijn gebruikt, is de ondezoeksgroep dus ook dezelfde. Deze onderzoeksgroep bestond uit 2032 leerlingen, die in 1978 de MAS hadden verlaten.

C. Het doel van het onderzoek is inzicht te krijgen in de functies, die MAO-gediplomeerden in het bedrijfsleven vervullen. Hiertoe zullen er beroepenbeschrijvingen nodig zijn.

D. Voor dit onderzoek is gebruik gemaakt van de gegevens van het eerder genoemde LEIonderzoek. Deze gegevens zijn verder aangevuld door middel van gesprekken met betrokkenen en deskundigen. In het in dit rapport beschreven onderzoek wordt nu geprobeerd tot beroepsbeschrijvingen te komen. Dit wordt bereikt door middel van een matrix met de elemten 'sector van de landbouw' en 'aard van de werkzaamheden'.

E. De voor dit onderzoek belangrijkste vragen zijn de vragen omtrent het huidige beroep van de respondent en omtrent de werkzaamheden waaruit dit beroep hoofdzakelijk bestaat.

F. De respons bij het LEl-onderzoek van 1983 was $1874 / 2032 * 100 \%=93,25 \%$.

G. De bij het onderzoek gebruikte indelingen zijn:

- een indeling naar agrarische functies op middelbaar niveau;

- een indeling naar sectoren van de landbouw;

- een indeling naar aard van werkzaamheden;

- een indeling naar beroepsbeschrijvingen. 
Dit zijn eigen indelingen.

H. Dit onderzoek is nog niet periodiek, maar wel bestaat het plan voor een vervolgonderzoek. Dit vervolgonderzoek zal plaats vinden in de vorm van een loopbaanonderzoek, dat door alle middelbare agrarische scholen dient te worden verricht. Om dan een landelijk overzicht te verkrijgen wordt er gebruik gemaakt van een standaard enquêteformulier met algemene vragen, vragen over de opleiding en de vervolgopleiding en vragen over de loopbaan. Dit loopbaanonderzoek is gericht schoolverlaters van het middelbaar agrarisch onderwijs, die vijf jaar tevoren de school hebben verlaten. Deze zou om de vijf jaar herhaald kunnen worden. Het doel van dit loopbaanonderzoek is een goed en actueel beeld te geven over de loopbanen en de beroepen van MAO-gediplomeerden. Aan de hand van de via de enquête vezamelde informatie kunnen dan beroepsprofielen ontwikkelt worden.

I. In het onderzoek zijn er geen prognoses gemaakt.

J. De opzet van het onderzoek en de resultaten van het onderzoek worden gepresenteerd in een rapport. In dit rapport wordt ook reeds de opzet van een mogelijk vervolgonderzoek uitéén gezet.

K. De Directie Landbouwonderwijs kan de bij dit onderzoek verkregen informatie gebruiken om een betere aansluiting te krijgen tussen het landbouwonderwijs en de beroepspraktijk. 


\section{VAKGROEP AGRARISCHE ONDERWIJSKUNDE, LANDBOUWUNIVERSITEIT WAGENINGEN}

5.1. Literatuurstudie voor doel en opzet van het MAO-Loopbaan-Onderzoek, H.J.Pierik, Vakgroep Agrarische Onderwijskunde, LU Wageningen, Wageningen, 1989.

A. De literatuurstudie is uitgevoerd door H.J.Pierik van de Vakgroep Agrarische Onderwijskunde van de LU in Wageningen ter voorbereiding op een plan voor verder onderzoek (zie 5.2).

B. De bestudeerde literatuur valt uitéen in drie delen. Ten eerste een verkenning van het werkveld: het MAO en het arbeidsmarktsegment waartoe dit opleidt. Ten tweede een hoeveelheid onderzoeksliteratuur, gericht op de relatie tussen arbeidsmarkt en onderwijs. De onderzoeksliteratuur op het terrein tussen arbeidsmarkt en onderwijs is grofweg te onderscheiden in een viertal ideaaltypen :

(1) functie- en beroepenanalyse;

(2) werkgelegenheidsonderzoek;

(3) loopbaanonderzoek;

(4) onderwijsevaluatie in het kader van outputkwaliteitsbeheer.

Ten derde is literatuur doorgewerkt met theorie over onderzoek op het gebied van onderwijs en arbeidsmarkt.

C. Het doel van deze literatuurstudie is een eerste houvast te krijgen op het onderzoeksveld. Zij moet uitmonden in een aantal toegespitste vragen over doel en opzet van het MAOLoopbaan-Onderzoek. In een gespreksronde met een aantal deskundigen worden deze vragen vervolgens bediscussieerd en ten slotte zal worden getracht de conclusies van deze gesprekken te vertalen in een projectplan.

De resultaten van dit onderzoek zijn gepresenteerd in een intern verslag. Er worden enkele conclusies getrokken, waaruit blijkt dat de literatuurstudie een aantal vraagpunten t.a.v. de onderzoeksvraagstelling en -methodiek opgeleverd. Deze punten worden verder uitgewerkt in een lijst van vragen die de te interviewen deskundigen op het gebied van onderzoek van onderwijs en arbeidsmarkt krijgen voorgelegd. Deze vragen en de antwoorden van de deskundigen daarop worden gegeven in een verslag over de gespreksronde.

5.2. De aansluiting tussen MAO en arbeidsmarkt, een projectplan voor onderzoek, Vakgroep Agragrische Onderwijskunde, Landbouwuniversiteit Wageningen, 1989.

A. Het projectplan "de aansluiting tussen MAO en Arbeidsmarkt" bevat een onderzoekplan naar 
de aansluitingsproblematiek tussen het MAO en de arbeidsmarkt en is opgesteld in 1989 door de Vakgroep Agrarische Onderwijskunde van de LU in Wageningen. Dit onderzoek heeft een tweetal doelstellingen. De eerste is het ontwikkelen en (éénmalig) beproeven van een continu signaleringssysteem van knelpunten in de aansluiting tussen het MAO en het bedrijfsleven. De tweede doelstelling is het opstellen van een feitelijke beschrijving van de beroepsloopbaan van ex-MAO-leerlingen en de verschuivingen die daarin nu en in de toekomst plaats zullen vinden. Hiervoor wordt gebruik gemaakt van een tweetal deelonderzoeken:

(1) Een enquête onder ex-leerlingen, als onderdeel van het loopbaanonderzoek. Deze enquête heeft in 1990 plaatsgevonden.

B. De onderzoekspopulatie bestond uit twee volledige cohorten ex-leerlingen van het MAO (MAO-A, MAO-B, KMAO en Deeltijd Onderwijs) uit de jaren 1978 en 1987.

C. De algemene doelstelling van dit onderzoek is onder punt $A$ reeds beschreven. Dit onderzoek moet een bijdrage leveren tot de beeldvorming over de soorten fricties en hun oorzaken.

D. Als onderzoeksmethode is gekozen voor een enquête in de vorm van een cohortonderzoek. Elke drie jaar worden twee volledige cohorten ex-leerlingen van het MAO benaderd met een vragenlijst. Elke generatie wordt meerdere keren benaderd, tot 5 à 6 jaar na het schoolverlaten.

E. De vragenlijst bevat een aantal vragen over achtergrondgegevens, vooropleiding, gegevens over MAO-opleiding, de aandacht voor de verschillende vakgebieden, de vaardigheden, de onderwijsuitvoering, het vervolg-onderwijs na het MAO, de maatschappelijke positie, de huidige hoofd-functie, het carriëreverloop, de functieloosheid en de toekomstperspectieven.

F. De respons bedroeg circa $54 \%$.

G. De bij het onderzoek gebruikte indelingen zijn :

- een uitsplitsing naar marktsector (eigen indeling);

- een uitsplitsing naar afdeling binnen het onderwijs (eigen indeling, verfijnder dan de SOI).

H. Het onderzoek zal vanaf 1989 regelmatig herhaald gaan worden, met tussenperiodes van drie jaar. 
I. Er worden geen prognoses opgesteld. Wel wordt er gevraagd naar de toekomstperspectieven.

J. De resultaten zijn weergegeven in een tabellenboek en in een globale onderzoeksrapportage.

K. De resultaten van dit onderzoek moeten in de eerste plaats gebruikt kunnen worden om de actuele discrepanties tussen onderwijs en arbeidsmarkt aan te pakken. Als doelgroep worden alle betrokkenen bij het Middelbaar Agrarisch Onderwijs gezien: bedrijfsleven, scholen en overheid.

(2) Delphi-onderzoek voor beleidsaanbevelingen (medio 1991).

B. De onderzoekspopulatie hiervoor zal bestaan uit een twaalftal deskundigen uit bedrijfsleven, onderwijs en overheid.

C. In het Delphi-onderzoek wordt gestreefd naar convergentie in de meningsvorming. Het Delphi-onderzoek vormt een aanvulling op het loopbaanonderzoek (deze laatste heeft plaats gevonden in de vorm van een enquête onder ex-leerlingen). De resultaten van dit loopbaanonderzoek worden in het Delphi-onderzoek vertaald in beleidsaanbevelingen aan onderwijsinstellingen, overheid en bedrijfsleven.

D. Het delphi-onderzoek zal als volgt verlopen: in een aantal opénvolgende rondes wordt de sleutelfiguren gevraagd naar hun visie op en oplossing van een bepaald probleem. Deze sleutelfiguren rapporteren dan schriftelijk de resultaten van deze eerste ronde terug, waarna wederom mondeling gevraagd wordt om de visies op de reacties van anderen. Men probeert zo tot een convergentie in de meningsvorming te komen.

E. De vraagstelling voor dit onderzoek is gebaseerd op de resultaten van de loopbaanenquête uit 1990. Er wordt gevraagd om een visie op de consequenties van de onderzoeksresultaten voor de inrichting van het Voortgezet Agrarisch Onderwijs. 



\section{REGIOPLAN, ONDERZOEK- EN ADVIESBUREAU VOOR REGIONALE ECONOMIE EN LOKALE ONTWIKKELING B.V.}

6.1. De oogst van de MAS, een onderzoek naar de uitstroom bestemming van gediplomeerden van het Middelbaar Agrarisch Onderwijs, drs. Marijke Braams, Regioplan, Amsterdam, april 1990.

A. In opdracht van de Directie Landbouwonderwijs van het Ministerie van Landbouw, Natuurbeheer en Visserij is door het onderzoeks- en adviesbureau Regioplan een onderzoek uitgevoerd naar de bestemming van gediplomeerden uit het middelbaar agrarisch onderwijs. Dit onderzoek is in 1990 door drs. M.Braams verricht.

B. Als onderzoeksdoelgroep is een deel van de schoolverlaters uit 1985, 1987 en 1989 genomen. In totaal zijn er 1260 oud MAS-sers telefonisch benaderd. Bij het samenstellen van deze steekproef is er op gelet dat alle vakrichtingen lop én na, "biologisch dynamische landen tuinbouw) en alle drie jaren goed vertegenwoordigd zijn in deze steekproef. Voor de benadering van de respondenten is gebruik gemaakt van de leerlingbestanden van de scholen. Aan de onderzoekspopulatie is verder een tweetal restricties gesteld. Ten eerste betreft het onderzoek uitsluitend gediplomeerden en ten tweede alleen gediplomeerden van de A- en B-leergangen van het voltijdonderwijs.

C. Doel van het onderzoek is een beeld te krijgen van de bestemming van schoolverlaters uit het middelbaar agrarisch onderwijs.

D. Het onderzoek heeft plaats gevonden in de vorm van een telefonische enquête. De argumenten hiervoor waren het zeer kort tijdbestek waarin het onderzoek moest worden uitgevoerd, het beperkt aantal vragen dat zich goed leende voor een telefonische benadering en het feit dat de respons bij een mondelinge ondervraging in de regel hoger is dan bij een schriftelijke vragenlijst.

E. Aan alle respondenten is gevraagd wat men direct na het schoolverlaten deed en wat de huidige bezigheden zijn. Verder zijn er nog vragen omtrent de achtergrond van de respondent gesteld, zoals geslacht, opleidingsrichting, jaar van diplomering etcetera.

F. Van de gehele steekproef is een antwoord verkregen.

Aan de representativiteit van het onderzoek kunnen een aantal kritische kanttekeningen geplaatst worden. Zo is er een grotere steekproef nodig om een zuivere beeld van de 
gegevens te krijgen op het niveau van vakrichtingen. Verder is voor het trekken van een steekproef uit 1985 op basis van de gegevens van de afgelopen vier jaar ('86-'89) een schatting gemaakt van het aantal gediplomeerden in 1985. Tevens zijn de gerigistreerde aantallen leerlingen en gediplomeerden niet altijd juist. De oorzaak hiervan ligt in de aanlevering van de gegevens door scholen en de registratie ervan door het Ministerie. Ten slotte worden leerlingen met een 'dubbeldiploma' (gediplomeerd in twee richtingen) als gediplomeerden onder de eerstgenoemde vakrichting geregistreerd. Hierdoor ontstaat een vertekend beeld van het werkelijke aantal gediplomeerden per vakrichting. Toch mag verondersteld worden dat de resultaten redelijke indicaties opleveren over de uitstroombestemming van gediplomeerden van de middelbare agrarische school.

G. De bij het onderzoek gebruikte indeling zijn:

- een indeling naar opleiding met twee hoofdcategorieën, die een verdere indeling naar opleiding kennen;

- een indeling naar functie met twee hoofdcategorieën die een verdere indeling kennen;

- een indeling naar sector, welke drie sectoren kent.

De laatste twee indeling zijn in samenwerking met de opdrachtgever samengesteld. Het zijn eigen indelingen.

H. Reeds in 1984 is door het Landbouw Economisch Instituut (LEI) een onderzoek naar de bestemming van schoolverlaters van de MAS verricht. Verder is er nog een onderzoeksrapport tot stand gekomen omtrent een beschrijving van de aard en inhoud van functies, die gediplomeerden van de MAS vijf jaar na het schoolverlaten bekleden. Dit onderzoek heeft echter reeds tien jaar geleden plaats gevonden. Het gebrek aan actuele informatie over de werkelijke bestemming van schoolverlaters van het middelbaar agrarisch beroepsonderwijs is de aanleiding geweest voor het huidige onderzoek.

I. Er worden geen prognoses gemaakt in dit onderzoek.

J. Het onderzoek wordt gepresenteerd in de vorm van een rapport. In dit rapport is als eerste het doel en de opzet van het onderzoek bekend gemaakt. Vervolgens worden de resulaten van het verwerken van de gegevens behandeld en ten slotte worden de uitkomsten van de enquête gegeven.

Over belemmeringen m.b.t. de toegankelijkheid van dit rapport wordt niets gezegd.

K. De Directie Landbouwonderwijs van het Ministerie van Landbouw, Natuurbeheer en Visserij zal gebruik maken van de resultaten van dit onderzoek. Zij zal deze resulaten gebruiken ter 
bevordering van een goede afstemming van het tokomstig beleid ten aanzien van het landbouwonderwijs.

6.2. De oogst van de MAS, vervolgonderzoek: een tweetal thema's nader bekeken, drs. M. Braams, Regioplan, Amsterdam, augustus 1990.

A. Het Ministerie van Landbouw, Natuurbeheer en Visserij heeft het onderzoek- en adviesbureau Regioplan de opdracht gegeven om een tweetal thema's uit het onderzoeksmateriaal van het onderzoek naar de bestemming van gediplomeerde schoolverlaters uit het middelbaar agrarisch onderwijs ("De oogst van de MAS", Regioplan, A'dam, april 1990) aan een nadere analyse te onderwerpen. Deze analyse is uitgevoerd door drs.M.Braams in augustus 1990.

B. De onderzoeksdoelgroep bevat nu geen personen maar de resultaten van een drietal onderzoeken, namelijk: "De oogst van de MAS", een onderzoek naar de bestemming van gediplomeerde schoolverlaters uit het middelbaar agrarisch onderwijs van Regioplan uit 1990, een vergelijkbaar onderzoek van LEI uit 1983 en het onderzoek "De HAO-ingenieur in functie $^{n}$ van de Stichting SHAO uit 1988.

C. Het doel van deze verdere analyse is een beter en gedetailleerder beeld te krijgen van de uitstroom en loopbaanontwikkelingen in het middelbaar agrarisch onderwijs.

D. Bij het eerste thema wordt een aantal bevindingen uit "De oogst van de MAS" gezet naast resultaten van een vergelijkbaar onderzoek van LEI. Een dergelijke vergelijking geeft inzicht in uitstroom en loopbaanontwikkelingen van middelbaar agrarisch geschoolden gedurende de afgelopen 12 jaar. In het tweede thema wordt nader ingegaan op de belangrijkste functies, die MAO-gediplomeerden vervullen in de verschillende sectoren van de agrarische arbeidsmarkt, en worden de utkomsten hiervan vergeleken met de positie van HAOgediplomeerden. Deze vergelijking geeft een indicatie van de opbouw van de agrarische arbeidsmarkt naar middelbaar en hoger onderwijsniveau.

E. In het eerste thema is op een vijftal bevindingen met elkaar vergeleken: de samenstelling van de onderzoekspopulatie, de keuze van vervolgonderwijs, de werkloosheid na de MAS, de aard van de eerste werkkring en de aard van de werkkring vijf jaar na de MAS. In het tweede thema wordt de arbeidsmarktpositie van de respondenten, die een agrarische functie bekleden, op het moment van de enquête (1990) nader geanalyseerd. Verder wordt er aandacht besteed aan de verdeling van de MAS-sers over de verschillende agrarische functies. Deze uitkomsten worden vergeleken met de situatie van hoger agrarisch 
geschoolden.

F. Respons komt in deze analyse niet voor, omdat het om een vergelijking van verschillende onderzoeken gaat.

G. De bij de analyse gebruikte indelingen zijn voor het eerste thema:

- een indeling naar drie sectoren (deze is gelijk aan de indeling gebuikt bij "De oogst van de MAS");

voor het tweede thema:

- een nieuwe indeling naar zes sectoren;

- een nieuwe indeling naar drie hoofdfuncties.

De indelingen zijn eigen indelingen.

H. Deze analyse is niet periodiek.

I. Er wordt geen gebruik gemaakt van prognoses.

J. De gehele analyse en de uitkomsten van deze analyse zijn gepresenteerd in een rapport.

K. Het Ministerie van Landbouw, Natuurbeheer en Visserij kan deze gedetailleerde informatie voor een nog betere afstemming van het toekomstig landbouwonderwijsbeleid. 


\section{STICHTING OPLEIDINGSFONDS LEERLINGWEZEN LAND- EN TUINBOUW (SOLLT)}

7.1. Het Leerlingwezen in de Land- en Tuinbouw, Groenvoorziening en Bloemenbranche en de Arbeidsmarkt, G.A.L.M. Dohmen, Vakgroep Sociologie van de Westerse Gebieden, Landbouwuniversiteit Wageningen, Wageningen, 1988.

A. Dit onderzoek naar de relatie van het leerlingwezen in de land- en tuinbouw, groenvoorziening en bloemenbranche en de arbeidsmarkt heeft plaats gevonden in de periode van augustus 1987 tot mei 1988. Het onderzoek is uitgevoerd door Ir. G. Dohmen bij de Vakgroep Sociologie van de Westerse Gebieden van de LU in Wageningen.

B. Er is sprake van twee onderzoeksdoelgroepen, namelijk de leerlingen en de werkgevers. Per groep is een apart onderzoek verricht. In de groep van werkgevers is nog een verdere indeling gemaakt in land- en tuinbouw, groenvoorziening en bloemenbranche. De groenvoorziening is weer in twee sectoren verdeeld, namelijk de hoveniersbedrijven en de gemeentelijke plantsoendiensten.

C. De doelstellingen van het onderzoek in zijn geheel luiden :

- een beeld te vormen van de arbeidsmarktontwikkelingen (zowel wat betreft de vraag naar als het aanbod van arbeidskrachten) die relevant zijn voor het Leerlingstelsel Land- en Tuinbouw, Groenvoorziening en Bloemenbranche;

- een beeld te vormen van de mate, waarin de opleiding van het leerlingstelsel voldoet aan de verwachtingen van zowel werkgevers als werknemers;

- te komen tot een analyse van de arbeidsmarktontwikkelingen in het verleden met als doel uitspraken te kunnen doen over te verwachten ontwikkelingen in de toekomst.

D. De onderzoeksmethode bestaat uit drie fasen :

1. Een oriënterende fase: deze houdt in het inventariseren en analyseren van het bestaande statistische en ander schriftelijk materiaal;

2. Het feitelijke onderzoek: op basis van de oriënterende fase dienen de leemten, die in het bronnenonderzoek zijn geconstateerd te worden aangevuld met eigen onderzoek;

3. Een analyse van de bevindingen.

Het feitelijk onderzoek bestaat hoofdzakelijk uit enquêtes bij de verschillende doelgroepen. Alleen bij de sector land- en tuinbouw is dit niet het geval.

* De enquêtes onder oud-leerlingen en huidige leerlingen van het leerlingstelsel hebben eind december 1987 en begin januari 1988 plaats gevonden. De steekproef is gekozen uit het bestand van alle oud-leerlingen, die in 1986 voor het examen zijn geslaagd, 
respectievelijk het bestand van leerlingen, die in 1987 aan de primaire opleiding zijn begonnen. De steekproef bestond uit 752 oud-leerlingen en 739 huidige leerlingen.

* Bij de land- en tuinbouwsector zijn aan de hand van gesprekken met informanten en literatuur de belangrijkste tendenzen in de verschillende bedrijfstakken behandeld.

* De enquêtes onder werkgevers in de groenvoorziening zijn apart afgenomen bij twee typen arbeidsorganisaties, namelijk de hoveniersbedrijven en de gemeentelijke plantsoendiensten. De steekproef, getrokken uit het ledenbestand van twee brancheorganisaties bij de hoveniersbedrijven, was 524 bedrijven groot. Bij de gemeentelijke plantsoendiensten zijn 402 gemeenten benaderd. Er is hier gekozen voor een steekproef uit het bestand van alle Nederlandse gemeenten met meer dan 5000 inwoners.

* Voor de enquête onder werkgevers in de bloemenbranche zijn 623 bloemenwinkels benaderd, die zijn getrokken uit het ledenbestand van de branche-organisatie.

E. Er zijn verschillende vragenlijsten gebruikt bij de doelgroepen:

* Bij het onderzoek in de land- en tuinbouw is gevraagd het aantal arbeidskrachten, naar het bedrijfstype, naar de werkzaamheden die verricht worden en naar leeftijd en geslacht van de werknemers.

* Bij het onderzoek in de groenvoorziening en in de bloemenbranche is eenzelfde vragenlijst gebruikt. Deze lijst bevat vragen omtrent de vereiste vooropleiding, het aantal werkzame personen, oorzaken van de verwachte veranderingen in het personeelsbestand, redenen voor het al dan niet aan nemen van stagiaires en/of leerlingen van het leerlingstelsel, behoefte aan bijscholing van huidig personeel, plaatsingsduur en leeftijd van de werknemers.

* Bij het onderzoek onder oud-leerlingen en huidige leerlingen zijn er vragen gesteld naar geslacht, leeftijd, opleidingsrichting, vooropleiding, schoolverlaters of niet, motivatie voor de opleiding en de mening en verwachtingen over de opleiding. Bij oud-leerlingen zijn dan nog vragen gesteld over het al dan niet vinden van een betaalde baan in de richting van de vakopleiding.

F. De respons van de enquêtes verschilt ook weer per groep.

* De respons bij leerlingen is te verdelen in een respons onder oud-leerlingen en een respons onder huidige leerlingen. Bij oud-leerlingen was de respons $413 / 752 * 100 \%=54,92 \%$. Van de 752 enquêtes bleken er echter 27 onbestelbaar te zijn, zodat de respons $413 / 725 * 100 \%=56,96 \%$ is. De respons bij de huidige leerlingen is $459 / 739 * 100 \%=62,11 \%$. Hiervan bleken 2 enquêtes onbestelbaar, waardoor de respons $459 / 737 * 100 \%=62,27 \%$ wordt.

* De respons van de enquête onder werkgevers in de groenvooziening valt uit éen in 
$194 / 524 * 100 \%=37,40 \%$ (met 6 onbestelbare enquêtes: $37,45 \%$ ) voor de hoverniersbedrijven en $211 / 402 * 100 \%=52,48 \% \quad(51,99 \%$ was geschikt voor verwerking) voor de gemeentelijke plantsoendiensten.

* De respons in de bloemenbranche is $241 / 623 * 100 \%=38,68 \%$. Er was één enquête onbestelbaar.

Over de representativiteit kan gezegd worden dat er bij het onderzoek onder leerlingen een regelmatige verdeling van de steekproef over de veschillende richtingen was. De representativiteit bij de werkgevers kan ook als redelijk beschouwd worden, omdat hier bij de verschillende sectoren steekproeven genomen zijn (de hoofdsectoren zijn dus allemaal vertegenwoordigd).

G. Ook bij de gebruikte indelingen moeten de twee groepen onderscheiden worden.

* Bij de leerlingen is er een indeling naar studierichting gemaakt en bij de oud-leerlingen ook nog naar het type bedrijf waarbij ze werkzaam zijn.

* Bij de werkgevers is er een indeling gemaakt naar de sectoren, zoals land- en tuinbouw, groenvoorziening en bloemenbranche.

Beide zijn eigen indelingen.

H. Het onderzoek heeft maar voor een korte periode plaats gevonden. Of dit onderzoek herhaald zal worden is niet bekend.

I. In dit onderzoek zijn onderwijsprognoses van het Centraal Plan Bureau opgenomen.

J. De resultaten zijn verwerkt in een rapport, waarin de belangrijkste resulaten vermeld zijn en waarin uitleg wordt gegeven bij de gebruikte werkwijze en onderzoeksmethoden.

K. De gebruikersgroep is het SOLLT en eventueel de vakopleidingen. Het doel van de vakopleidingen in het algemeen is enerzijds om voldoende vakbekwame mensen op te leiden voor de betreffende bedrijfstakken, anderzijds om mensen een grotere kans te geven op de arbeidsmarkt na afronding van hun opleiding. De afstemming van het aanbod van vakgeschoold personeel op de vraag ernaar kan met behulp van de resultaten van dit onderzoek misschien verbeterd worden. 